\title{
Modele edytorskie XIX-wiecznych polskojęzycznych wydań Nowego Testamentu - próba identyfikacji
}

\author{
Editorial Models of 19th-Century Polish-Language Editions of the New Testament - \\ An Attempt at Identification
}

\author{
Eukasz Zakonnik \\ Uniwersytet Łódzki \\ lukasz.zakonnik@uni.lodz.pl \\ https://orcid.org/0000-0003-1842-7558
}

\begin{abstract}
The presented article reviews publications of 19th century Polish New Testament in order to find editorial models upon which subsequent editions were based. The work considers 68 editions published between 1815-1900. The first half of them were based on the translation adopted in the Danzig Bible and the second half on the translation by Jakub Wujek. Among the analyzed editions, 27 were identified, according to which subsequent Polish New Testament were published (in the 19th century). In addition to the editorial models indicated, the work also proposes 7 editing lines.
\end{abstract}

KeYwords: Bible, New Testament, Holy Bible, editions of the New Testament list, editorial models, Bible translations into Polish, Wujek Bible, Gdansk Bible

SŁowA KluCzowe: Biblia, Nowy Testament, Pismo Święte, spis wydań Nowego Testamentu, modele edytorskie, polskie przekłady Pisma Świętego, Biblia Wujka, Biblia Gdańska

Prezentowane opracowanie jest kontynuacją wcześniejszych badań autora, zaprezentowanych w artykule nt. modeli edytorskich XIX-wiecznych polskich Biblii (opisano w nim wydania, które zawierały zarówno księgi Starego Testamentu [ST], jak i Nowego Testamentu $[\mathrm{NT}])^{1}$. Wybór wieku XIX uzasadniono we wspomnianym artykule. Przedstawienie modeli edytorskich edycji całościowych $(\mathrm{ST}+\mathrm{NT})$ nie wydawało się autorowi kompleksowym ukazaniem problematyki, na którą składają się z jednej strony różnorodność, z drugiej - podobieństwo ukazujących się polskojęzycznych publikacji tekstu Pisma Świętego w badanym okresie. Należy zauważyć, że w XIX wieku ukazały się przynajmniej 62 całościowe wydania Biblii, podczas gdy edycji NT było co najmniej $84^{2}$. Przyczyny są następujące: łączny druk ST i NT był często zbyt drogi dla uboższych warstw społeczeństwa (np. chłopów); ST dla wielu odbiorców mógł się wydawać zbyt trudny, dlatego nie odczuwano potrzeby

1 Ł. Zakonnik, „Modele edytorskie XIX-wiecznych polskich Biblii - próba identyfikacji”, BibAn 11/2 (2021) 327-374.

2 Zestawienie wszystkich odnalezionych wydań XIX-wiecznych zostało przedstawione w artykule: Ł. Zakonnik, „Biblie w języku polskim wydane w latach 1801-1945”, ABMK 116 (2021) 483-532. 
jego całościowego czytania ${ }^{3}$ (poza Księgą Psalmów, często dołączaną do NT i traktowaną jako kluczową w wielu praktykach religijnych ${ }^{4}$ ); wydanie kompletnej Biblii wiązało się z większym prawdopodobieństwem odrzucenia takiego druku przez władze różnych denominacji chrześcijańskich (argumentujących swe działania błędami tłumaczenia lub niekompletnością tekstu) 5 . W związku z powyższym nie dziwi fakt ukazywania się różnorodnych i licznych edycji samego NT (ewentualnie z dołączoną Księgą Psalmów). Jak wspomniano, badania autora pozwoliły zidentyfikować łącznie 84 (a właściwie 82$)^{6}$ takie publikacje w języku polskim. Część z nich (10 druków) oferowano zazwyczaj do nabycia wraz z oddzielnym wydaniem ST. Edycje te omówiono przy okazji wydań łączonych ST+NT. W artykule uwzględniono więc głównie 72 publikacje, choć w pełni opisano 68 (4 wydania uznano za zaginione). Ponadto w artykule poruszono kwestie nieukończonych edycji NT (udało się zidentyfikować trzy takie druki). Zasadniczym celem prezentowanego opracowania jest przegląd poszczególnych wydań NT w języku polskim, które ukazały się w wieku XIX, i określenie możliwych modeli edytorskich. W przypadku znacznego podobieństwa między poszczególnymi modelami wyodrębniono i opisano główne linie edytorskie. W artykule jako materiał badawczy wykorzystano dostępne w Internecie kopie cyfrowe ${ }^{7}$ wydań oraz druki z kolekcji prywatnych ${ }^{8}$.

3 Przykładowo w XIX wieku ukazała się aprobowana przez Kościół katolicki w Polsce edycja ST, która nie tylko pomijała całe fragmenty tekstu poszczególnych ksiąg, ale nawet całe księgi (uznano je za zbyt trudne do zrozumienia lub po prostu niezalecane do czytania). Chodzi tu o edycję ST wydaną w Poznaniu w $1891 \mathrm{r}$. (por. M. Kossowska, Biblia wjęzyku polskim [Poznań: Księgarnia św. Wojciecha 1969] II, 117).

$4 \quad$ Rola Księgi Psalmów, jako uprzywilejowanej formy modlitwy, rosła w Kościołach chrześcijańskich już od pierwszych wieków - por. I. Bodrožić, „Proces nastanka liturgije časova i kršćansko poimanje vremena u kontekstu benediktinske duhovnosti i pravila", Slovo 71 (2021) 1-25.

5 Problem akceptacji konkretnych wydań Biblii jest dość złożony. Z jednej strony niektóre z powstających towarzystw biblijnych nie chciały drukować żadnych dodatków do Biblii (np. komentarzy) ani ksiąg wykraczających poza kanon hebrajski ST (zob. B. Enholc-Narzyńska, „Teksty biblijne w przekładzie ks. Jana Jakuba Wujka, ich wydania i rozpowszechniane przez Towarzystwo Biblijne w Polsce w XIX i XX wieku", Jan Jakub Wujek ttumacz Biblii na język polski [red. M. Kamińska] [Łódź: Archidiecezjalne Wydawnictw Łódzkie 1994] 138). Z kolei Kościół katolicki w Polsce nie aprobował innych przekładów poza Biblią Wujka z 1599 r. i umieszczonymi tam komentarzami (choć tu wykazują pewną elastyczność), a także zwracał uwagę na imprimatur (zob. W. Smereka, „Zarys bibliograficzny ważniejszych wydań Biblii ks. Jakuba Wujka (1593-1950)”, RBL 3 [1950] 73-74).

6 Dwa spośród 84 wydań wykluczono, ponieważ najprawdopodobniej ukazały się już w XX wieku (nie podano w ich przypadku dokładnej daty publikacji) (zob. Zakonnik, „Biblie w języku polskim”, 510).

$7 \quad$ Hiperlącza do kopii cyfrowych zaprezentowano w załączniku.

8 Opisując każdy model, autor starał się porównywać przynajmniej 2 egzemplarze każdego wydania. Czasami między egzemplarzami pojawiały się pewne różnice typograficzne, jednak o minimalnym znaczeniu. 


\section{Opis podstawowych modeli edytorskich}

Opisując poszczególne modele edytorskie, autor zdecydował się przyjąć układ wykorzystany we wcześniejszej pracy, poświęconej całościowym wydaniom Biblii. Początkowo zaprezentowano - w ujęciu chronologicznym - informacje o kolejnych, uznanych za wzorcowe wydaniach NT. Przedstawiane zestawienie zostało podzielone na dwie części. W pierwszej opisano edycje NT opierające się̧ na tłumaczeniu zawartym w Biblii Gdańskiej (NTBG), w kolejnej - druki oparte na thumaczeniu ks. Jakuba Wujka (NTBW ${ }^{10}$. W przypadku Biblii Gdańskiej wliczono do niej wydania związane z tzw. rewizją warszawską (umieszczono je jednak w oddzielnych podpunktach). Twórcy wspomnianej rewizji odwoływali się do Biblii Gdańskiej, aczkolwiek obydwa tłumaczenia cechuje odmienność ${ }^{11}$. W związku z tym, że poszczególne modele są często zbliżone pod względem edytorskim, w opisie nie zaprezentowano wszystkich szczegółów. Zebrano je w formie tabelarycznej w kolejnym punkcie pracy (tab. 1). W zestawieniu zrezygnowano z omawiania wydań NT bezpośrednio powiązanych z wydaniem całościowym Biblii. Jeżeli wydanie ukazywało się jako wyraźnie wydzielone w stosunku do ST (np. w innym roku), wzmianka o nim pojawia się w artykule. W zestawieniu zasygnalizowano też wydania nieodnalezione. Wspomniano również o znanych wydaniach zaplanowanych, które nie ukazały się w całości.

\subsection{Edycje NT Biblii Gdańskiej}

\subsubsection{Berlin $1828 \mathrm{r}$.}

Pełny tytuł brzmi: „Nowy Testament PANA naszego JEzusa Chrystusa Z Greckiego Języka na Polski pilnie i wiernie przetłumaczony, A teraz podług Edycyi Gdańskiey z Roku 1632 I Edycyi Królewieckiey z Roku 1738 powtórnie przedrukowany.”.

9 Użyto sformułowania „opierające się” w związku z tym, że zarówno pierwotne tłumaczenie zawarte w BG, jak i w BW ulegały z czasem większym bądź mniejszym modyfikacjom. Tematyka ta, choć sygnalizowana, jest jednak poza zakresem prezentowanego opracowania.

10 Zastosowanie takiego układu ułatwia wykazywanie podobieństw między edycjami. Listę rozpoczęto od BG, ponieważ pierwsza wydrukowana polska Biblia w XIX wieku ukazała się według tłumaczenia BG (Berlin 1810). Poza wydaniem całościowym ukazał się oddzielnie NT (łączony z Księgą Psalmów). Ze względu na przyjętą w artykule zasadę sam druk z 1810 r. nie został uwzględniony w tym opracowaniu (omówiono go w: Zakonnik, „Modele edytorskie”, 330-331).

11 Tzw. rewizja warszawska (dotycząca jedynie tekstu NT), według twórców, była nowym tłumaczeniem, jedynie porównanym z tekstem BG (informację taką umieszczano np. na kartach tytułowych poszczególnych wydań). Szczegółowa analiza przekładów potwierdza ten stan rzeczy (zob. BibliePolskie.pl http://bibliepolskie.pl/ przeklady.php?tid=23 [dostęp: 25.09.2021]). Warto jednak zaznaczyć, że już wcześniej miały miejsce pewne modyfikacje tekstu obydwu przekładów Biblii. BG miała być pierwotnie korektą Biblii Brzeskiej (por. T. Sznajderski, „Reformacja i polskie przekłady Biblii”, ZRL 60/4 [2017] 79-81), a XVIII wiek przyniósł zmiany w tekście, tzw. rewizja królewiecka. W przypadku Biblii Wujka zauważalne różnice wystąpiły między tekstem, który ukazał się w 1593 (1594) r., a tekstem z 1599 r. (por. R. Pietkiewicz, Biblia Polonorum. I. Od poczattku do 1638 roku [Poznań: Pallottinum 2016] 458-459). 


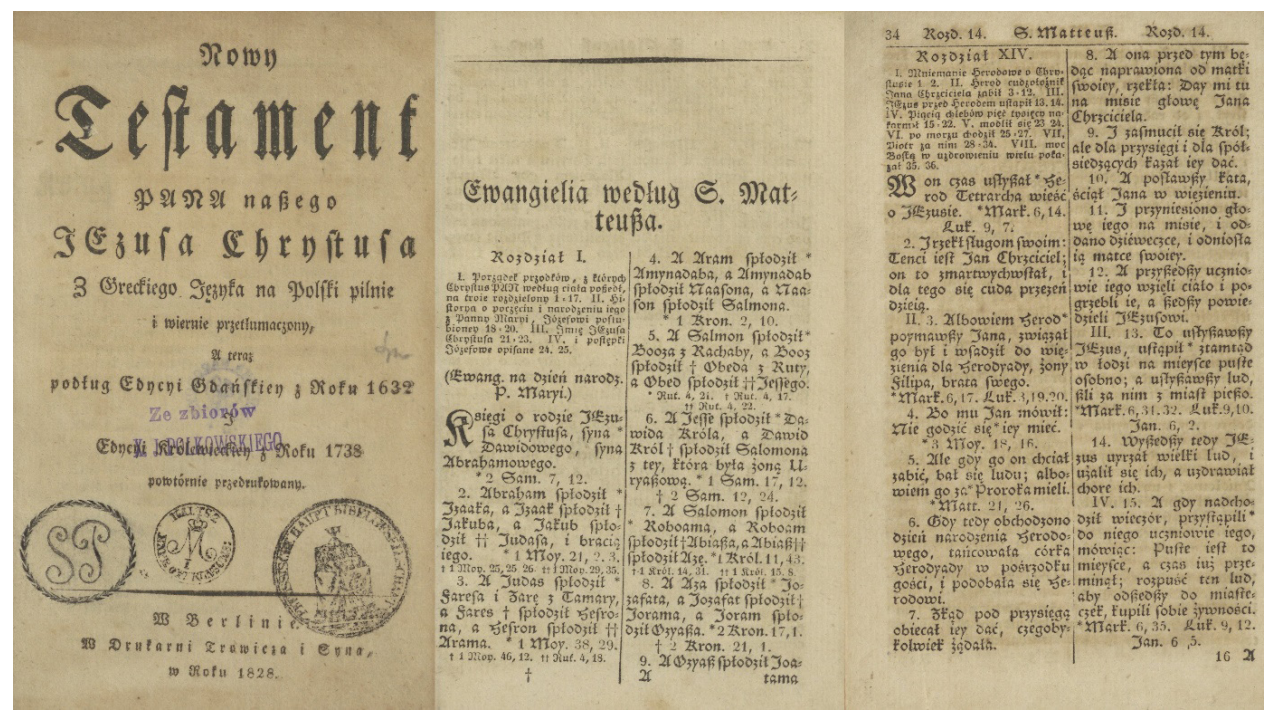

Rys. 1. NTBG, wydanie z roku 1828

Źródło: Biblioteka Narodowa, https://polona.pl [dostęp: 12.06.2021].

Pierwszy z przedstawianych modeli nawiązuje jeszcze do XVIII-wiecznych założeń edytorskich ${ }^{12}$. Zawiera on stosunkowo bogaty zestaw elementów dołączonych do tekstu głównego: wyróżnienie zapisu nomina sacra, konkordancje, streszczenie przed każdym rozdziałem, wykaz ewangelii i lekcji oraz - z czym spotkamy się bardzo rzadko w wydaniach XIX-wiecznych - wskazanie na „najprzedniejsze wyroki i sentencje”13. Na dole strony umieszczono kustosz (później już nieużywany). Dwukolumnowy druk w czcionce gotyckiej pozbawiony jest elementów graficznych, poza inicjałami na początku każdego rozdziału (co staje się standardem dla wydań NT w XIX wieku). Do żywej paginy (nagłówka) trafia tytuł księgi w języku polskim, numer rozdziału i strony. Strona tytułowa informuje o zgodności z BG z 1632 r., ale w tzw. rewizji królewieckiej (jest to najczęściej wykorzystywana modyfikacja tłumaczenia BG w drukach XIX-wiecznych). Warto zwrócić uwagę na zapis słów: „ewangielia” oraz imienia Jezus (pisanego przez J). Numeracja rozdziałów wykorzystuje rzymski zapis cyfr. Analizowana edycja nie doczekała się wznowień w identycznej postaci.

12 Podobny układ można zaobserwować np. w wydaniu NT z 1728 r. z Lipska (por. Google Books, https:// books.google.pl/books?id=nyEVAAAAQAAJ\&printsec=frontcover\&hl=pl\# $\mathrm{v}=$ onepage\&q \&f=false [dostęp: 12.06.2021]). Jest to jednak podobieństwo stosunkowo odległe, ponieważ samo tłumaczenie uległo pewnej korekcie w Królewcu w 1738 r. (tzw. rewizja królewiecka).

13 W analizowanych drukach oznaczane albo specjalnymi znakami (np. symbolem rączki i listka), albo pogrubioną czcionką. Wskazywano w ten sposób na najistotniejsze lub najbardziej znane fragmenty Pisma Świętego. 


\subsubsection{Lipsk 1832 r.}

Pełny tytuł brzmi: „Nowy Testament PANA naszego JEzusa Chrystusa Z Greckiego Języka na Polski pilnie i wiernie przetłumaczony, A teraz podług Edycyi Gdańskiey z Roku 1632 I Edycyi Królewieckiey z Roku 1738 powtórnie przedrukowany.”.

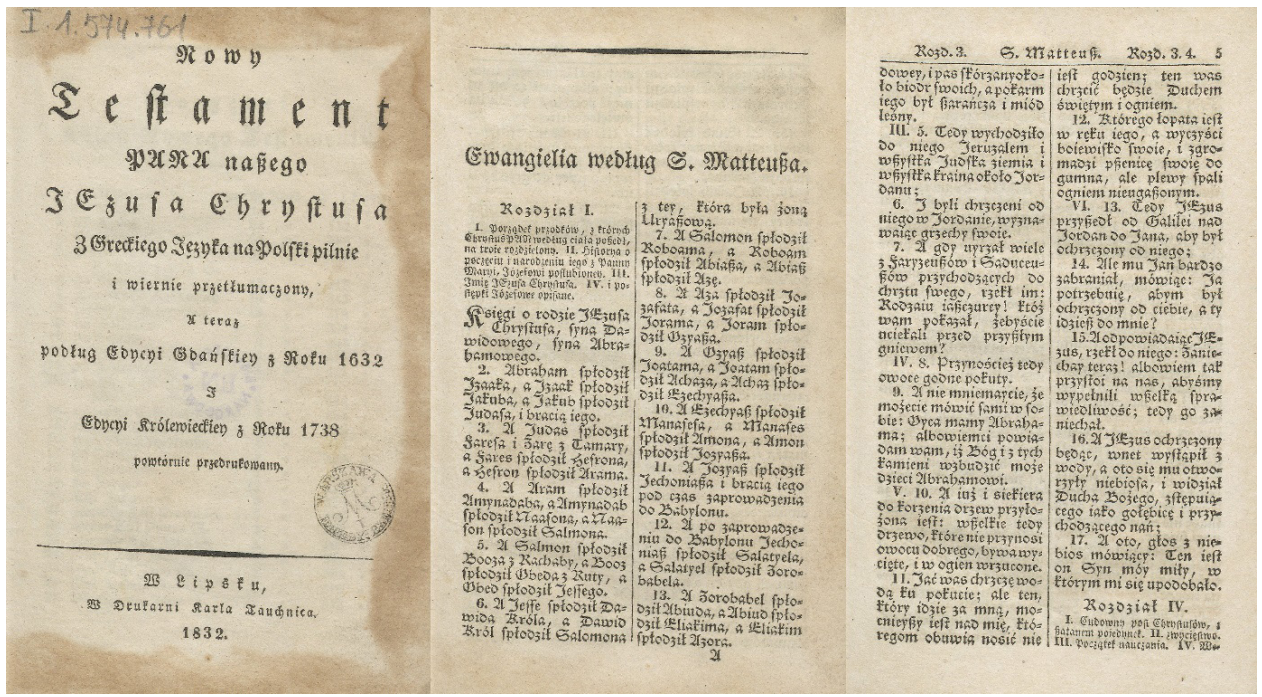

Rys. 2. NTBG, wydanie z roku 1832

Źródło: Biblioteka Narodowa, https://polona.pl [dostęp: 12.06.2021].

Wydanie z 1832 r. czerpie z rozwiązań zastosowanych w modelu poprzednim, m.in. opiera się na BG w tzw. rewizji królewieckiej i zostało wydrukowane przy użyciu czcionki gotyckiej. Jest jednak drukiem zdecydowanie uboższym. Pominięto w nim elementy dodatkowe (brak „najprzedniejszych wyroków i sentencji”, spisu ewangelii i lekcji czy konkordancji) - pozostawiono jedynie wyróżnienie nomina sacra. Zapewne celem tego wydania było ograniczenie kosztów i przekonanie do kupna jak największej liczby polskich niekatolików (warto zaznaczyć, że istniała już edycja tego samego wydawcy z roku 1830 - i lat późniejszych - kierowana do katolików). Cel zapewne został osiągnięty, gdyż publikacja doczekata się pięciu wznowien ${ }^{14}$.

14 Daty i miejsca kolejnych edycji wskazano w tabeli 1. 


\subsubsection{Warszawa $1834 \mathrm{r}$.}

Pełny tytuł brzmi: „NOWY TESTAMENT PANA NASZEGO JEZUSA CHRYSTUSA, Z GRECKIEGO JEZZYKA NA POLSKI PILNIE I WIERNIE PRZETŁUMACZONY, A TERAZ, PODŁUG WYDANIA AMSTERDAMSKIEGO Z ROKU 1660, ZGODNEGO Z BIBLIĄ GDAŃSKĄ Z ROKU 1632 DLA WYZNAŃ EWANGELICKICH, PRZEDRUKOWANY.”.

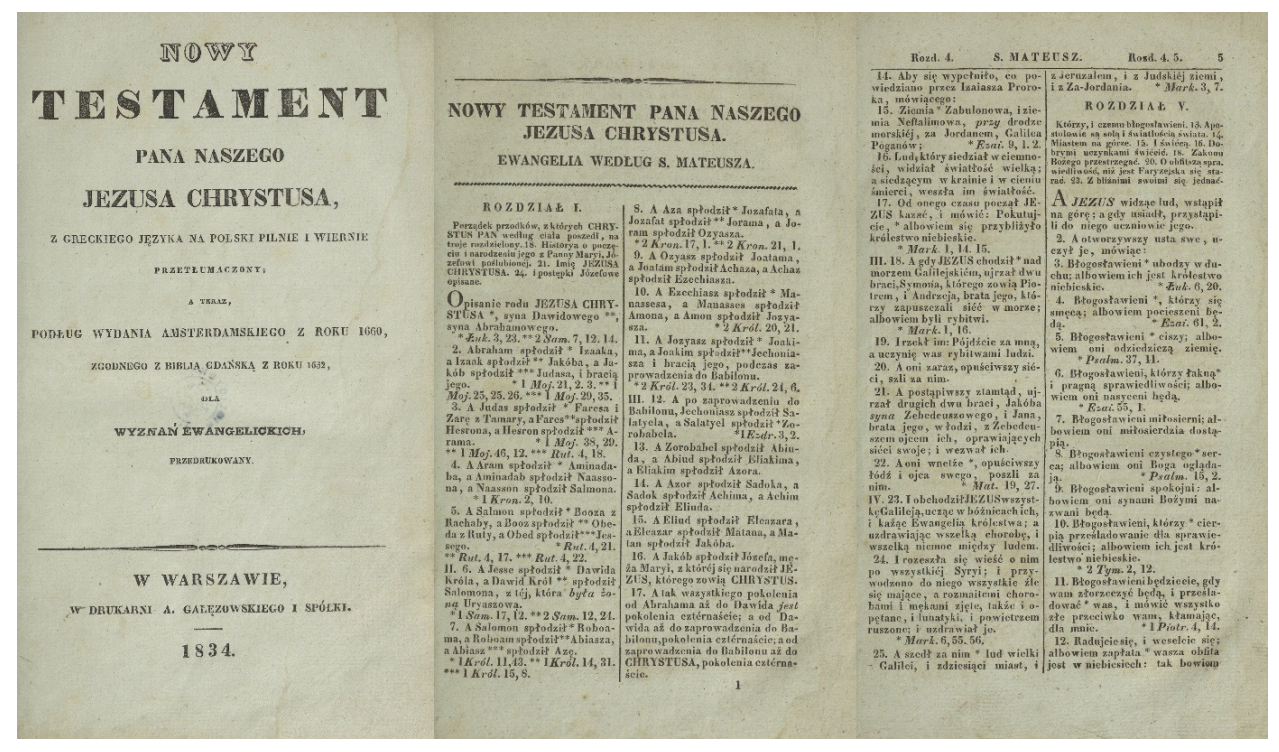

Rys. 3. NTBG, wydanie z roku 1834

Źródło: Biblioteka Narodowa, https://polona.pl [dostęp: 12.06.2021].

NT wydany w Warszawie w 1834 r. jest w kilku aspektach wyjątkowy. Został wydrukowany przy pomocy antykwy (prawdopodobnie po raz pierwszy w całej historii NTBG). Po raz pierwszy w XIX wieku nagłówek przyjmuje - często stosowaną później - postać, gdzie na stronie recto umieszczono tytuł księgi po polsku, a na stronie verso po łacinie (jest też miejsce na numer rozdziału i strony). Warto też odnotować, że na stronie tytułowej znajduje się nawiązanie do BG, ale w edycji amsterdamskiej z 1660 r. (a więc tekst opiera się na pierwotnym tłumaczeniu, a nie na popularnej już w tamtych czasach „rewizji królewieckiej” ma to miejsce tylko jeden raz w XIX wieku). Słowo „ewangelia” zapisane jest zgodnie z dzisiejszą normą językową (w XIX wieku w takiej formie występuje tylko w dwóch modelach NTBG). Sama książka jest prawie największą wśród analizowanych w tym opracowaniu $(22,5$ x $14 \mathrm{~cm})$. Druk nie doczekał się kolejnych wznowień. Gdyby pominąć Gdańsk (szczególnie biorąc pod uwagę jego specyficzną pozycję w Rzeczpospolitej Obojga Narodów), edycja ta byłaby pierwszym znanym drukiem BG ukazującym się na ziemiach polskich (a minęło ponad 200 lat od pierwodruku). 


\subsubsection{Warszawa 1852 r.}

Pełny tytuł brzmi: „NOWY TESTAMENT PANA NASZEGO JEZUSA CHRYSTUSA.”

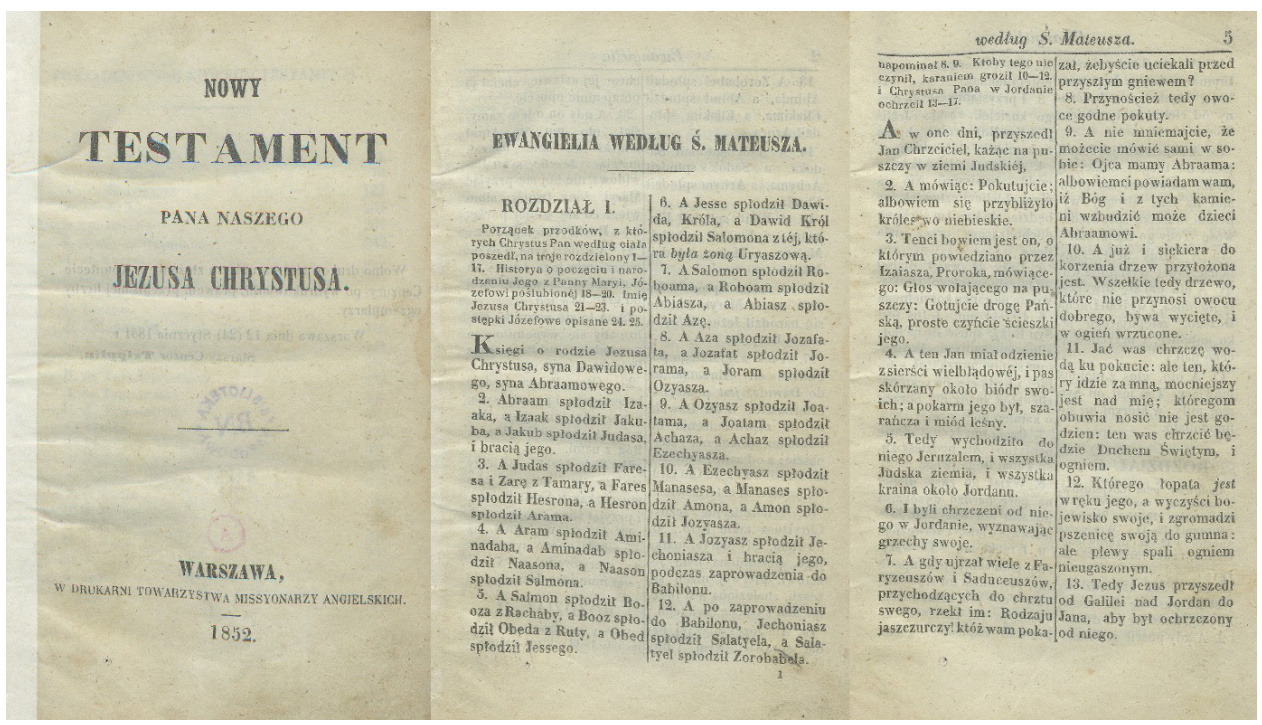

Rys. 4. NTBG, wydanie z roku 1852

Źródło: Biblioteka Narodowa, https://polona.pl [dostęp: 12.06.2021].

Analizowany model ma pewne cechy wspólne z poprzednim: było tylko jedno takie wydanie, miejscem publikacji była Warszawa, użyto antykwy oraz zastosowano podobny układ tekstu. Brakuje natomiast wielu elementów dodatkowych, zarówno w tekście głównym, jak i poza nim (występuje tylko streszczenie przed rozdziałem oraz spis treści). Nagłówek zawiera jedynie tytuł księgi po polsku i numer strony. Również sam układ strony tytułowej jest dość prosty - nie ma na niej żadnej wzmianki, która mogłaby sugerować wariant tłumaczenia. Sam tekst można jednak zidentyfikować jako NTBG oparty na „rewizji królewieckiej”. W tekście głównym ponownie wrócono do zapisu słowa „ewangielia”. 


\subsubsection{Londyn $1853 \mathrm{r}$.}

Pełny tytuł brzmi: „NOWY TESTAMENT PANA NASZEGO JEZUSA CHRYSTUSA PODŁUG EDYCYI GDAŃSKIEJ, PRZEJRZANY I PRZEDRUKOWANY.”.

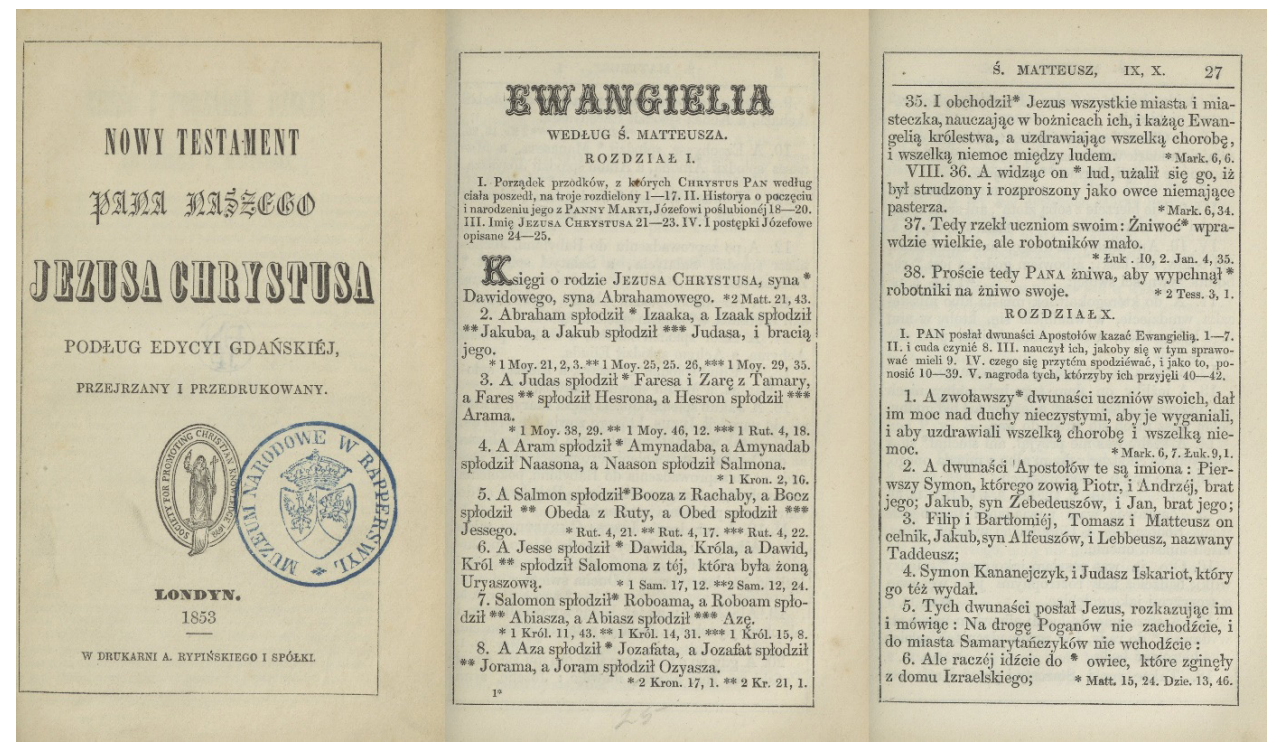

Rys. 5. NTBG, wydanie z roku 1853

Źródło: Biblioteka Narodowa, https://polona.pl [dostęp: 12.06.2021].

Opisywane wydanie zamyka listę trzech druków, które ukazały się tylko raz i prezentowały dość niepowtarzalny układ edytorski. O ile jednak obydwa wydania warszawskie nawiązują - w większym lub mniejszym stopniu - do ogólnych wzorców stosowanych w XIX wieku, o tyle analizowane wydanie znacznie od nich odbiega. Tekst znajduje się w 1 kolumnie otoczonej ramką (taką formę miały wydania NTBW z XVI i XVII wieku). Pojawia się sygnet drukarski. Na stronie tytułowej znajduje się fraza: „podług edycyi gdańskiej przejrzany i przedrukowany”, choć sam tekst bazuje na „rewizji królewieckiej”. W wydaniu zamieszczono bardzo rozbudowany spis treści. Druk antykwą wykorzystuje ozdobne inicjały (jednak tylko na początku każdej księgi, czego nie stosowano w innych wydaniach NTBG aż do ostatniego dziesięciolecia XIX wieku). Wyróżniono zapis nomina sacra i użyto słowa „ewangielia”. W tekście pojawiają się uwagi dotyczące innych możliwości tłumaczenia konkretnych słów (oznaczone literą G). Co ciekawe, formy te zostały wprowadzone później do tekstu głównego w tzw. rewizji warszawskiej ${ }^{15}$.

15 Można tu postawić pytanie, czy analizowane wydanie nie wpłynęło na przygotowywanie wspomnianej rewizji (porównaj punkty 1.1.12 i 1.1.13)? Zagadnienie to jednak wykracza poza ramy tego opracowania. 


\subsubsection{Berlin $1862 \mathrm{r}$.}

Pełny tytuł brzmi: „Nowy Testament Pana naszego Jezusa Chrystusa. Z Greckiego ięzyka na Polski pilnie i wiernie przetłumaczony.".

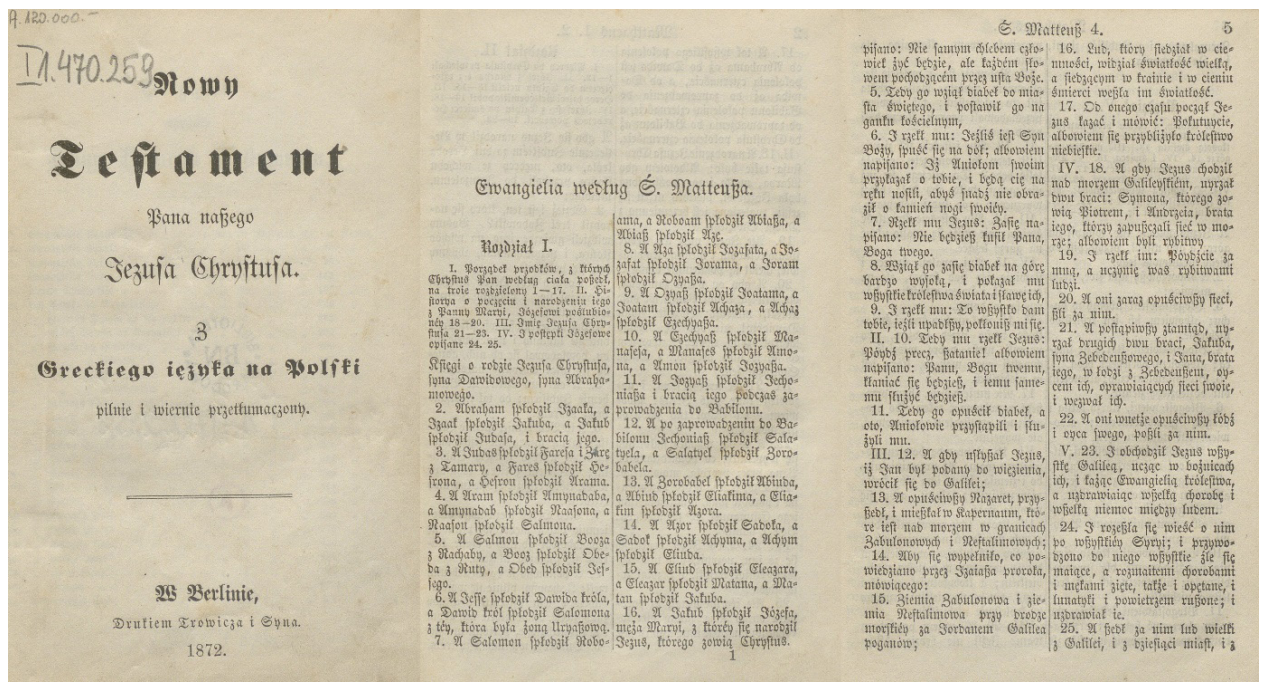

Rys. 6. NTBG, wydanie z roku 1862

Źródło: Zdjęcie wydania z 1872 r. - Biblioteka Narodowa, https://polona.pl [dostęp: 12.06.2021].

Model berliński zapoczątkowany wydaniem z $1862 \mathrm{r} .^{16}$ ukazał się w czcionce gotyckiej. Ze wszystkich drukowanych tym typem czcionki był najmniejszy oraz najprostszy pod względem edytorskim. W dwukolumnowym układzie tekstu zabrakło miejsca na jakiekolwiek elementy dodatkowe, poza streszczeniem przed każdym z rozdziałów. Pewnym novum dla wydań z czcionką gotycką było umieszczenie polskiej nazwy księgi na stronie recto i łacińskiej na stronie verso (obok numeru rozdziału oraz strony). Jako element wyróżniający w tekście pozostał tylko bardzo mały inicjał na początku każdego rozdziału. Wydanie to zapoczątkowało - często stosowaną później - praktykę umieszczania na stronie tytułowej informacji o tłumaczeniu „z greckiego języka” jako jedynej mogącej wskazywać na pochodzenie przekładu. Jednocześnie nie zamieszczono jakiejkolwiek informacji wskazującej na BG. Po raz kolejny zastosowano leksem „ewangielia”. Wydanie doczekało się 4 wznowień.

16 Istnieje pewna wątpliwość, czy takim drukiem pierwotnym nie była nieodnaleziona publikacja z 1858 r. - patrz punkt 1.1.9. 
1.1.7. Berlin $1866 \mathrm{r}$.

Pełny tytuł brzmi: „NOWY TESTAMENT PANA NASZEGO JEZUSA CHRYSTUSA Z GRECKIEGO JĘZYKA NA POLSKI PILNIE I WIERNIE PRZETŁUMACZONY.”.

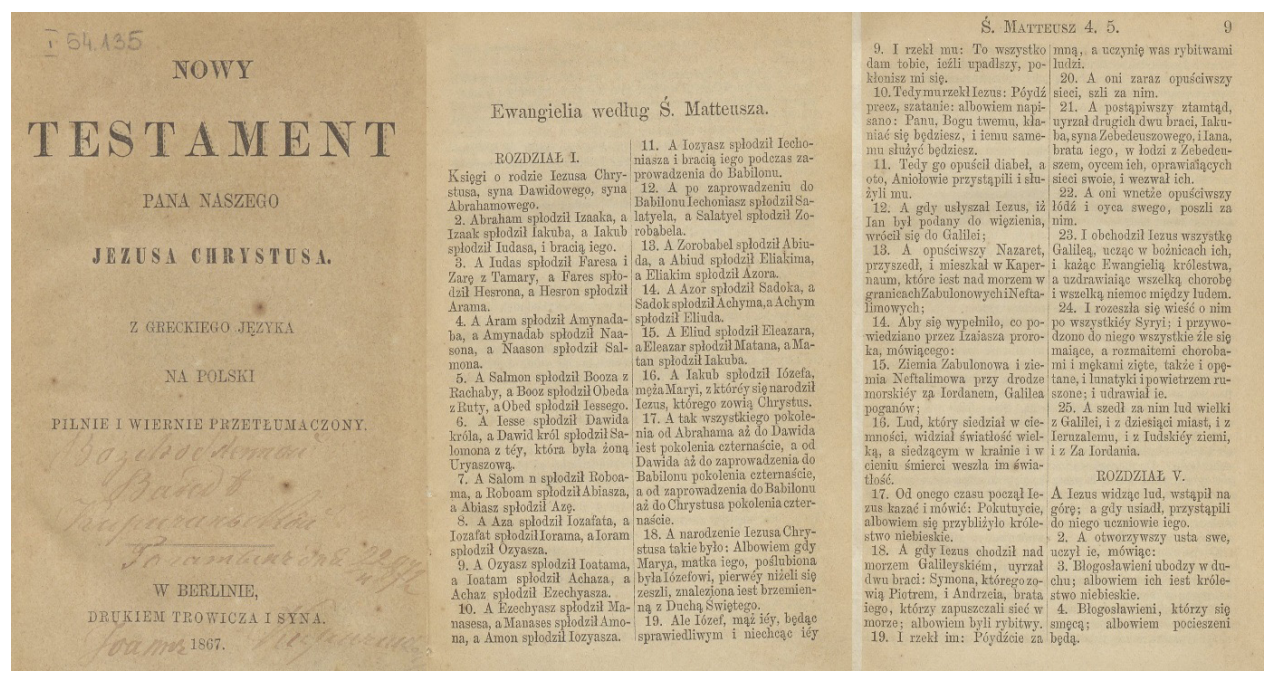

Rys. 7. NTBG, wydanie z roku 1866

Źródło: Zdjęcie wydania z 1867 r. - Biblioteka Narodowa, https://polona.pl [dostęp: 12.06.2021].

Analizowana edycja wydaje się być dość prosta, powtarza bowiem rozwiązania wykorzystane w modelu omawianym wcześniej. Posiada jednak pewne cechy nowatorskie. Po pierwsze, ukazała się w antykwie (było to więc pierwsze wydanie NTBG wydrukowane w krajach niemieckich tą czcionką). Po drugie, nie zawierała streszczeń przed rozdziałami. A po trzecie, imię Jezus zapisano przy użyciu litery I. W obydwu ostatnich przypadkach miało to miejsce pierwszy raz w XIX-wiecznych wydaniach NTBG. Ze względu na niezbyt rozbudowaną strukturę (a przez to niską cenę zakupu) wydanie doczekało się dwóch wznowień.

\subsubsection{Wiedeń $1867 \mathrm{r}$.}

Pełny tytuł brzmi: „NOWY TESTAMENT PANA NASZEGO JEZUSA CHRYSTUSA. Z GRECKIEGO JĘZYKA NA POLSKI PILNIE I WIERNIE PRZETŁUMACZONY.”.

Edycja ta ${ }^{17}$ jest wiedeńską kopią wcześniej omawianego wydania berlińskiego. Wyróżnia ją mały rozmiar (jeden z najmniejszych) $-11,5 \times 7 \mathrm{~cm}$. Druk cechował się też pewnymi nowatorskimi rozwiązaniami: po raz pierwszy w XIX-wiecznym wydaniu NTBG użyto

17 Elektroniczna wersja dostępna jest w usłudze Google Books, zob. https://books.google.pl/books?id=WFGJ6Cj119gC\&pg=PP1\&dq=Nowy+Testament+Pana+naszego+Jezusa [dostęp: 12.06.2021]. 
cyfr arabskich do numeracji rozdziałów, a po raz drugi - leksemu „ewangelia”. Wydanie nie doczekało się wznowienia.

1.1.9. Berlin $1873 \mathrm{r}$.

Pełny tytułbrzmi: „NOWYTESTAMENT PANANASZEGOJEZUSA CHRYSTUSA. Z GRECKIEGO JEZZYKA NA POLSKI PILNIE I WIERNIE PRZETŁUMACZONY.".

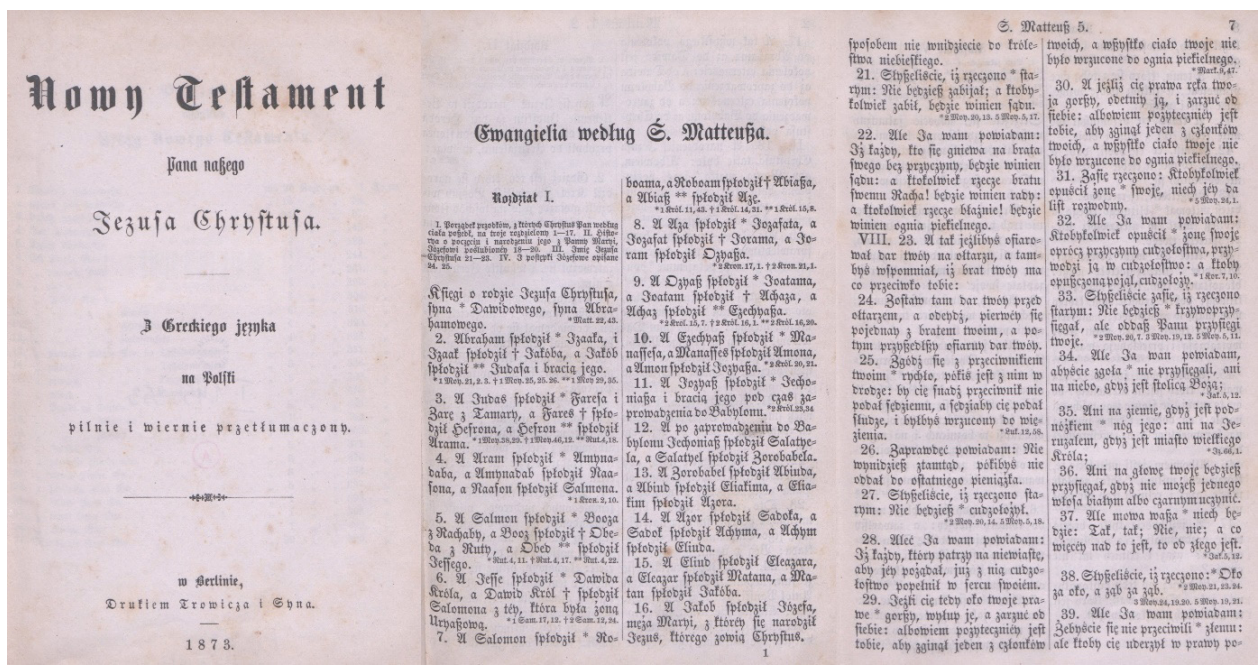

Rys. 8. NTBG, wydanie z roku 1873

Źródło: Biblioteka Narodowa, https://polona.pl [dostęp: 12.06.2021].

Opisywana edycja przypomina wydanie berlińskie z roku 1862, jednak w odróżnieniu od niego umieszczono w niej konkordancje. Taką samą liczbę stron ma wydanie z $1858 \mathrm{r} .{ }^{18}$ - niestety tego druku nie udało się odnaleźć. Gdyby jednak były to wydania tożsame, to oczywiście rocznik 1858 stałby się wzorcem dla opisywanej edycji (jak i pośrednio dla wydania z 1862 r.). Kolejnych wznowień nie odnotowano.

1.1.10. Wiedeń 1877 r.

Pełny tytuł brzmi: „NOWY TESTAMENT PANA NASZEGO JEZUSA CHRYSTUSA, Z GRECKIEGO JĘZYKA NA POLSKI PILNIE I WIERNIE PRZETŁUMACZONY.".

18 Wspomina o nim Karol Estreicher (Bibliografia polska XIX. stulecia [Kraków: Uniwersytet Jagielloński 1870] IV, 501-502). Wydanie to pojawiło się także w 2016 r. na aukcji internetowej portalu Allegro.pl (zob. https:// archiwum.allegro.pl/oferta/nowy-testament-i-psalmy-1858-biblia-pismo-swiete-i6331251770.html [dostęp: 12.06.2021]). 


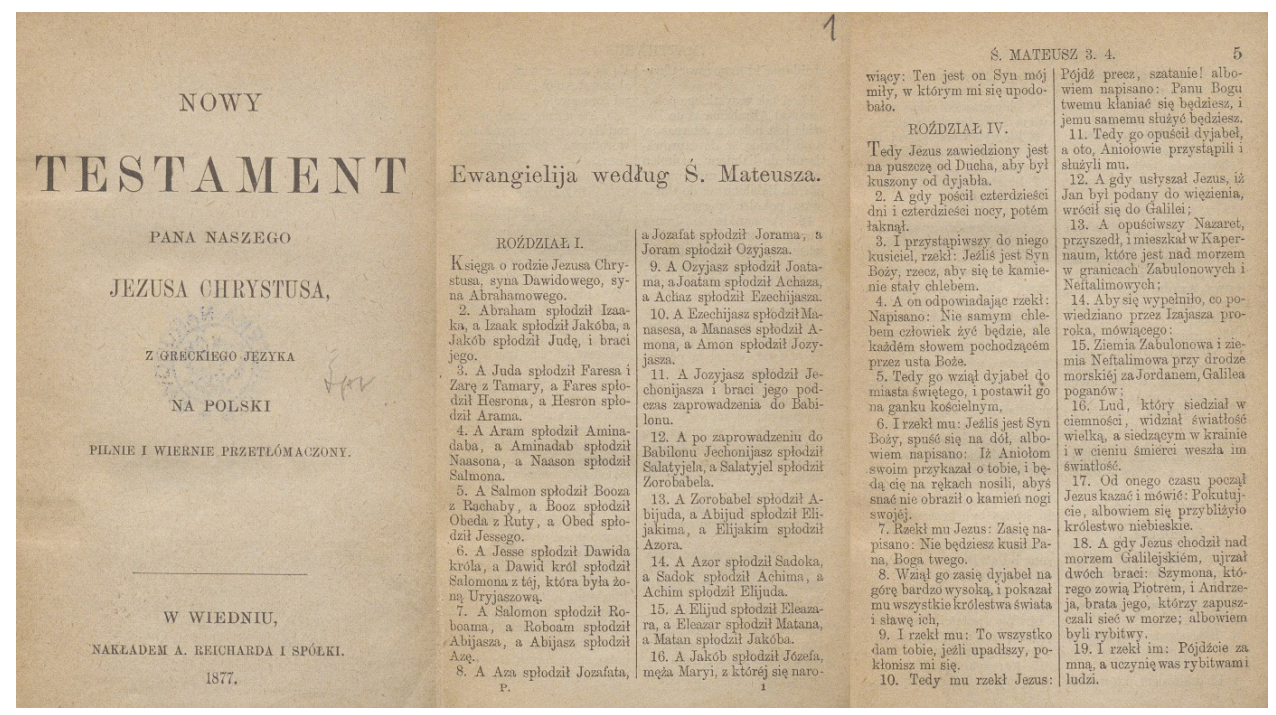

Rys. 9. NTBG, wydanie z roku 1877

Źródło: Biblioteka Narodowa, https://polona.pl [dostęp: 12.06.2021].

Model wiedeński, zapoczątkowany drukiem z 1877 r., opierał się na „rewizji królewieckiej" i był prawdopodobnie najczęściej wykorzystywanym dla wydań NTBG w historii ( 6 wznowień w XIX wieku i kolejne - przynajmniej 25 - w pierwszej połowie XX wieku ${ }^{19}$. Model jest wierną kopią wydania berlińskiego z 1866 r. Zwraca jednak uwagę inny układ tekstu, czego konsekwencją jest zmiana liczby stron w wydaniu ( 446 stron w porównaniu do 416). Inne są również formy zapisu słowa „ewangelia” (w analizowanym przypadku „ewangielija") oraz imienia Jezus (pisanego standardowo przez J, a nie I). Należy zaznaczyć, że w druku z 1877 r. paginacja biegnie od 1 do 446, ale od drugiej reedycji zmieniła się: rozpoczyna się od 5 i kończy na 450.

\subsubsection{Berlin $1898 \mathrm{r}$.}

Pełny tytuł brzmi: „Nowy Testament Pana naszego Jezusa Chrystusa. Z Greckiego języka na Polski pilnie i wiernie przetłumaczony.".

Rozpatrywany model nie różni się znacznie od edycji z 1873 r. Zwraca jednak uwagę wyróżnienie tzw. najprzedniejszych wyroków i sentencji (co miało miejsce wcześniej tylko raz - w przypadku wydania z 1828 r.). Pozostałe różnice dotyczą użycia inicjałów wyłącznie na początku każdej z ksiąg oraz wykorzystania cyfr arabskich w numeracji rozdziałów. Edycja nie doczekała się wznowienia w XIX wieku (jedno pojawiło się w wieku XX) ${ }^{20}$.

19 Por. Zakonnik, „Biblie w języku polskim”, 488-521.

20 Zakonnik, „Biblie w języku polskim”, 513. 


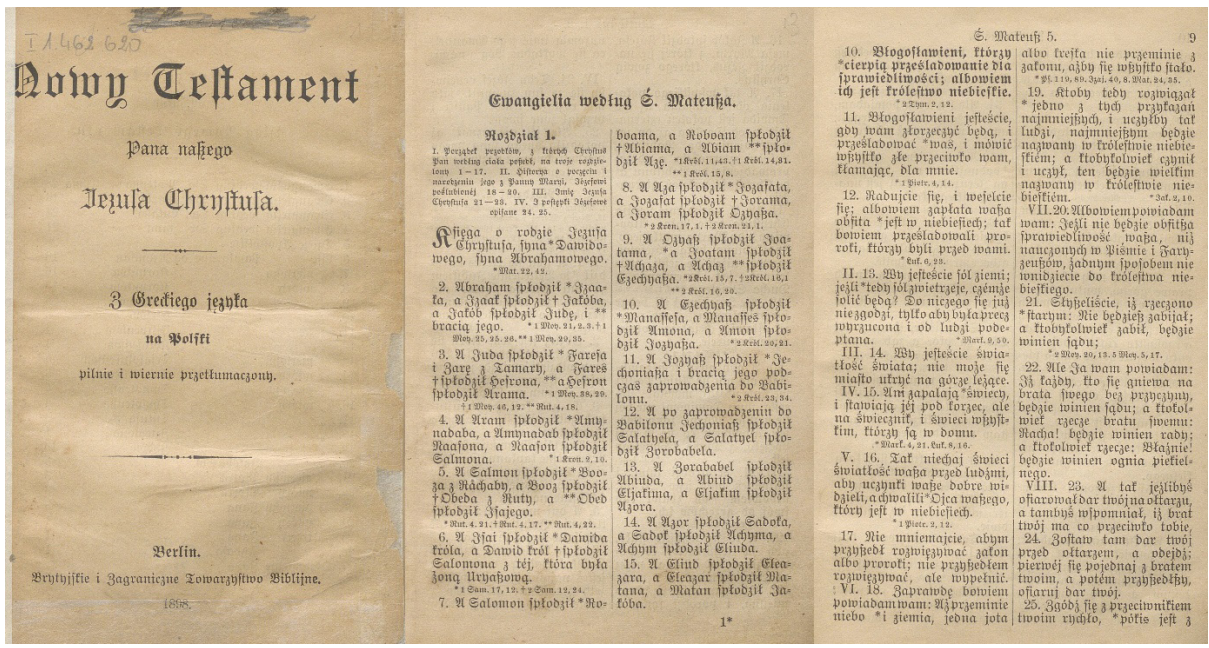

Rys. 10. NTBG, wydanie z roku 1898

Źródło: Biblioteka Narodowa, https://polona.pl [dostęp: 12.06.2021].

Dwa kolejne punkty przedstawiają wydania NT związane z powstaniem tzw. rewizji warszawskiej. Ich wydzielenie wynika z dostrzegalnych różnic w tekście tłumaczenia.

\subsubsection{Londyn $1876 \mathrm{r}$.}

Pełny tytuł brzmi: „NOWY TESTAMENT PANA NASZEGO JEZUSA CHRYSTUSA NA NOWO PRZEJRZANY Z TEXTU GRECKIEGO (PRZEZ KAROLA HR. WEGIERSKIEGO).”.

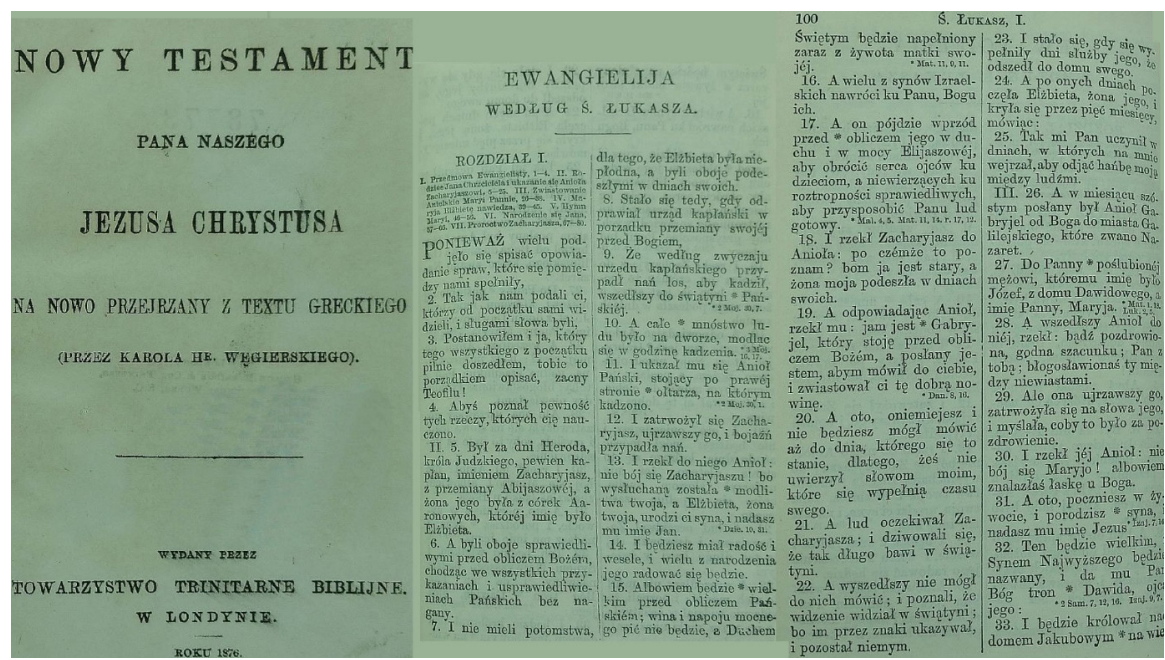

Rys. 11. NTBG, wydanie z roku 1876

Źródło: BibliePolskie.pl (za zgodą portalu), http://bibliepolskie.pl/przeklady.php?tid=101 [dostęp: 12.06.2021]. 
Analizowany druk prezentuje dość unikalny układ typograficzny (podobnie było w przypadku wydań warszawskich [1834, 1852] i londyńskiego [1853]). Zostały do niego wprowadzone również poważne zmiany w tłumaczeniu tekstu ${ }^{21}$, które następnie wykorzystano - z pewnymi modyfikacjami i uzupełnieniami - w tzw. rewizji warszawskiej (kolejne wydania od 1881 r. $)^{22}$. Druk, który przypomina wydania berlińskie (1866) i wiedeńskie (1867), różni się od nich pod wieloma względami. W nagłówku zrezygnowano z używania łacińskich tytułów ksiąg NT, wrócono do stosowania streszczeń przed kolejnymi rozdziałami, przywrócono wykaz miejsc paralelnych. Wprowadzono również zapis pierwszego wyrazu rozdziału wersalikiem (z zachowaniem inicjału) oraz użyto leksemu „ewangielija”. Edycja, dokładnie w takiej postaci, nie ukazała się już ponownie.

\subsubsection{Wiedeń $1881 \mathrm{r}$.}

Pełny tytuł brzmi: „NOWY TESTAMENT PANA NASZEGO JEZUSA CHRYSTUSA. Z JĘZYKA GRECKIEGO NA NOWO PRZEŁOŻONY Z TŁOMACZENIEM POLSKIEM Z ROKU 1632 PORÓWNANY.”.

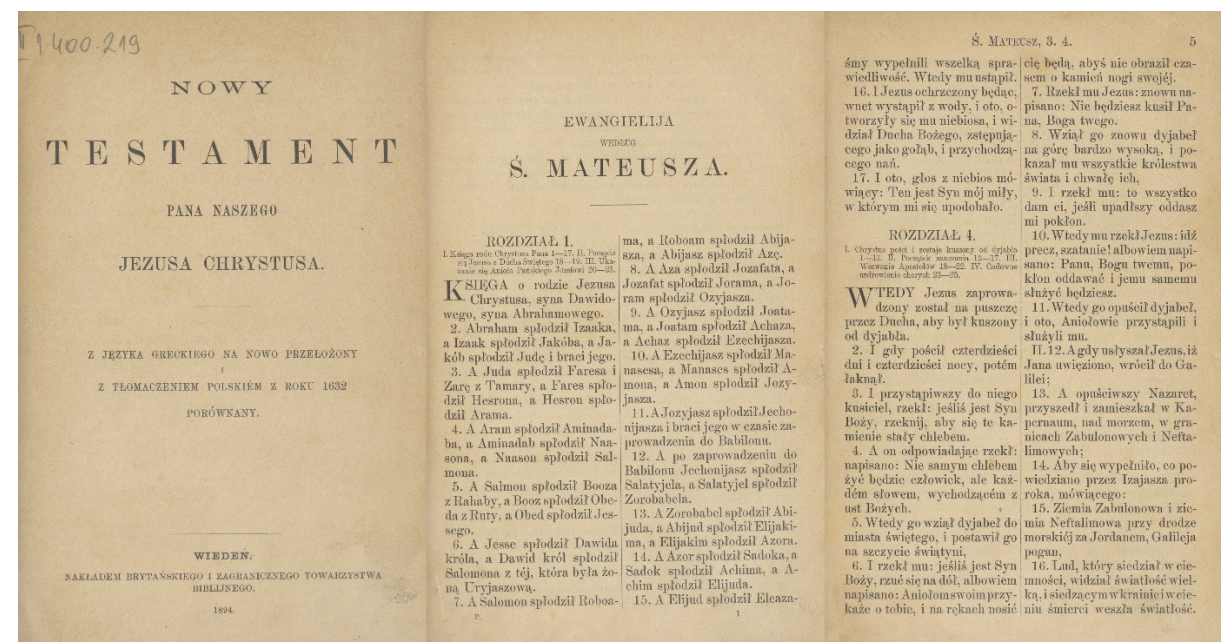

Rys. 12. NTBG, wydanie z roku 1881

Źródło: Zdjęcie wydania z 1894 r. - Biblioteka Narodowa, https://polona.pl [dostęp: 12.06.2021].

Ostatni z opisywanych modeli NTBG nawiązuje do druku londyńskiego z 1876 r. Jednak to właśnie on został uznany za punkt odniesienia dla „rewizji warszawskiej”.

$21 \quad$ Należy zauważyć, że pewne korekty tłumaczenia w formie uwag do tekstu zawarto już w wydaniu londyńskim z 1853 r. (patrz punkt 1.1.5).

22 Tekst hr. Węgierskiego i „rewizji warszawskiej”, choć mają tę samą genezę, nie są ze sobą bezpośrednio związane. Kwestia ta została opisana w artykule: G. Manitius, „Historia rewizji warszawskiej Biblii Gdańskiej [1881] i przekładu NT hr. Węgierskiego [1876]", http://bibliepolskie.pl/zzartykuly.php?art_id=15 [dostęp: 12.06.2021]). 
Do dostrzegalnych różnic, od strony edytorskiej, należy zaliczyć: zrezygnowanie z konkordancji, dołączone mapki oraz zastosowanie w numeracji rozdziałów cyfr arabskich. Dodatkowo na stronie tytułowej - obok wzmianki o wykorzystaniu języka greckiego jako źródłowego - pojawiła się znamienna informacja o tłumaczeniu jedynie „porównanym” z rokiem 1632 (a więc jest to „na nowo przełożone” tłumaczenie NT). Edycja była wznawiana jeszcze wielokrotnie ( 4 wznowienia w XIX wieku i przynajmniej $7 \mathrm{w}$ pierwszej połowie $\mathrm{XX}$ wieku). Stanowi ona tym samym pewną alternatywę dla NTBG wydanego w Wiedniu w 1877 r. oraz kolejnych jego wznowień.

\subsubsection{Wydania nieodnalezione oraz informacje dodatkowe}

Na podstawie różnych źródeł można wskazać jeszcze przynajmniej dwa wydania, których jednak autorowi nie udało się odnaleźć:

- wydanie wydrukowane we Wrocławiu w 1855 r. (wydawca Gras, Barth i Komp); ma liczyć 434 strony $^{23}$;

- wydanie wydrukowane w Berlinie w 1858 r. (wydawca Trowicz i Syn); ma liczyć 421 stron $^{24}$.

W zestawieniu zrezygnowano ze wskazywania wydań NT, które pojawiały się równocześnie jako samodzielne edycje oraz jako część całości Biblii. W ten sposób były publikowane praktycznie wszystkie wydania BG, przynajmniej do połowy XIX wieku.

\subsection{Edycje NT Biblii Wujka}

\subsubsection{Petersburg $1815 \mathrm{r}$.}

Pełny tytuł brzmi: „NOWY TESTAMENT PANA NASZEGO IEZUSA CHRISTUSA. EDYCYI WULGATY TŁUMACZENIA X. IAKUBA WUYKA z WĄGROWCA THEOLOGA SOCIETATIS IESU.".

NT wydany w Petersburgu stanowi materialny dowód prężnej, choć krótkotrwałej działalności Towarzystwa Biblijnego na terenach Rosji2 ${ }^{25}$. Pierwszy raz katolickie tłumaczenie Wujka zostało wydane przez organizację niekatolicką. Sytuacja taka będzie miała miejsce jeszcze wielokrotnie w XIX wieku, co poskutkuje pewnymi komplikacjami w powszechnej akceptacji dzieła. Druk - w celu zachęcenia katolików do zakupu - został zaopatrzony

23 W katalogu Biblioteki Narodowej pod tym rokiem wspominany jest tylko druk NT z wydania całościowego BG (z odmienną liczbą stron). Uwzględniony on został jednak np. w katalogu Worldcat (zob. https://www. worldcat.org/title/nowy-testament-pana-naszego-jezusa-chrystusa-v-greckiego-jezyka-na-polski-pilnie-i-wiernie-przetumaczony/oclc/1090947683 [dostęp: 12.06.2021]).

24 Informacje o tym wydaniu i jego potencjalne pokrewieństwo z wydaniem berlińskim z 1873 r. opisano w punkcie 1.1.9.

25 Towarzystwo Biblijne w Rosji rozpoczęło swą trzynastoletnią działalność w roku 1813, uzyskawszy istotne wsparcie cara Aleksandra I (zob. G. Pełczyński, „Ewangeliczni chrześcijanie-baptyści w Rosji i Związku Radzieckim", Sensus Historiae 4/3 [2011] 79). 
w kartę z biskupią aprobatą ${ }^{26}$, a sam tekst opierał się na tłumaczeniu z roku $1599^{27}$ (po raz pierwszy w historii samodzielnych edycji NTBW). W wydaniu wykorzystano antykwę (co stało się standardem dla kolejnych publikacji tego typu) i jednokolumnowy układ tekstu (stosowany przed XIX wiekiem, ale raczej już nie w wydaniach XIX-wiecznych). W nagłówku umieszczono zapisany po polsku tytuł księgi oraz numer strony. Wyróżniono zapis nomina sacra. Brak jest wskazania na „najprzedniejsze wyroki i sentencje” (podobnie zresztą jak we wszystkich NTBW ${ }^{28}$. Wstawiono streszczenie przed każdym z rozdziałów (czego nie praktykowano w nierosyjskich wydaniach NTBW). Publikacja zawiera także kartę z listą błędów (erratę zawierają również kolejne druki rosyjskie NT, nie ma jej jednak w drukach z innych regionów). W tekście zastosowano słowo „ewanielia”, a imię Jezus zapisywano przez I. Edycja jest pozbawiona elementów ilustracyjnych - zabrakło nawet inicjałów rozpoczynających kolejne rozdziały. Publikacja nie została już wznowiona w identycznym układzie.

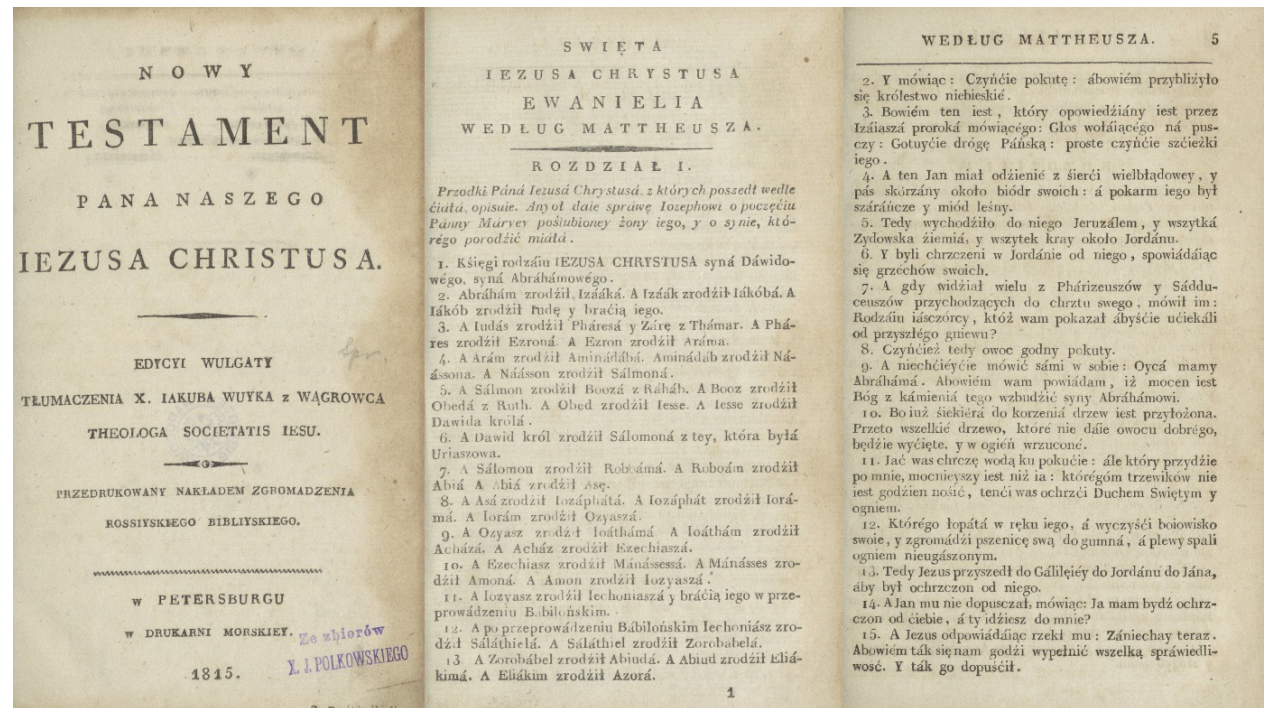

Rys. 13. NTBW, wydanie z roku 1815

Źródło: Biblioteka Narodowa, https://polona.pl [dostęp: 12.06.2021].

26 Biskupem tym był Stanisław Bohusz Siestrzeńcewicz (1731-1826). Aprobata została wydana samowolnie i była mocno krytykowana - zob. Smereka, „Zarys bibliograficzny”, 74 .

27 Czyli po korekcie komisji jezuickiej oraz domniemanej akceptacji papieża i synodu piotrkowskiego z 1607 r. Pogląd zakładający, że aprobata papieska oznacza brak zgody na jakąkolwiek rewizję tekstu czy nowy przekład Biblii dla polskich katolików bez ponownej zgody papieża, panował praktyczne do końca XIX wieku (por. R. Pietkiewicz, Biblia Polonorum. V. Biblia Tysiaclecia (1965-2015) [Poznań: Pallottinum 2015] 76-77).

28 W druku (podobnie jak to ma miejsce w wydaniu moskiewskim z 1819 r., ale nie z 1821 r.) można zauważyć kilkadziesiąt wierszy oznaczonych gwiazdką (Łk 1,47-80). 


\subsubsection{Moskwa 1819 r.}

Pełny tytuł brzmi: „NOWY TESTAMENT PANA NASZEGO IEZUSA CHRISTUSA. EDYCYI WULGATY Thumaczenia X. Iakuba Wuyka z Wągrowca Theologa Societatis Iezu.".

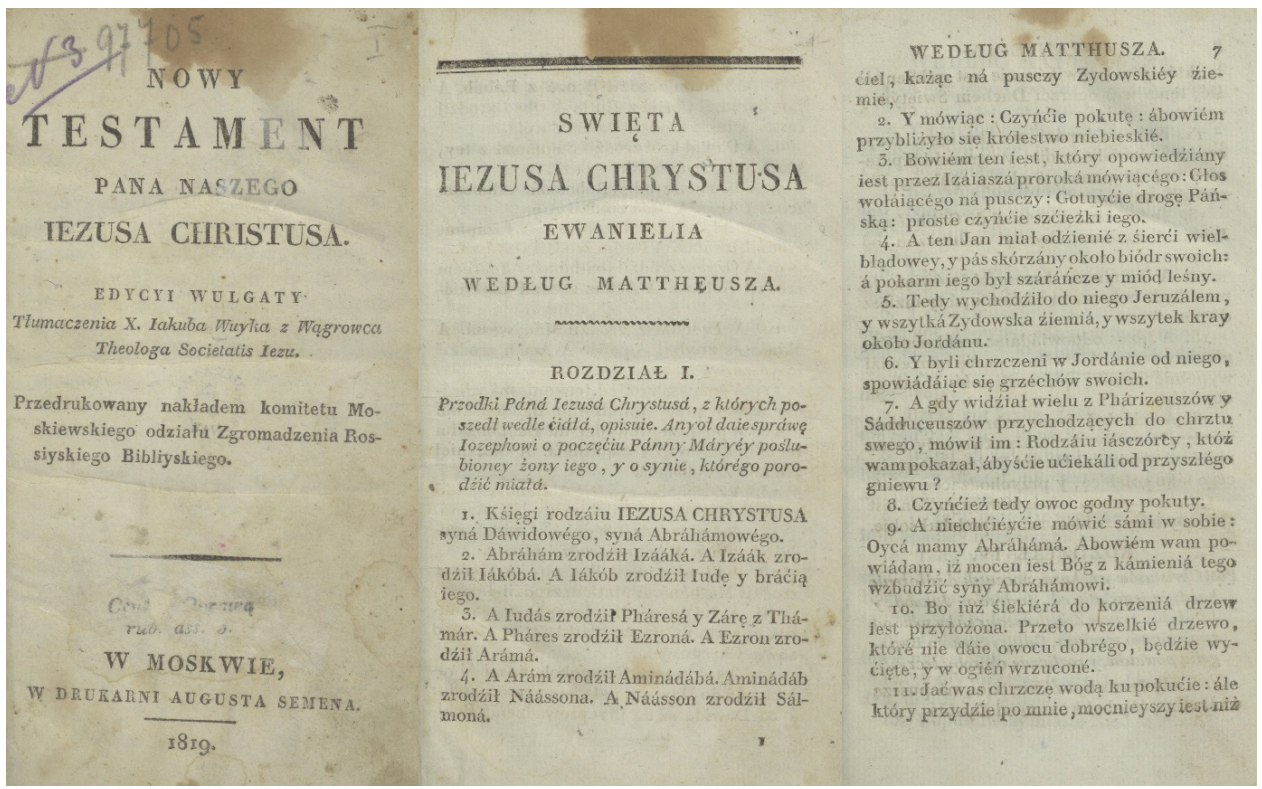

Rys. 14. NTBW, wydanie z roku 1819

Źródło: Biblioteka Narodowa, https://polona.pl [dostęp: 12.06.2021].

Wydanie moskiewskie z 1819 r. i petersburskie z 1815 r. ukazały się praktycznie według identycznego wzorca. Zasadniczą różnicę stanowił rozmiar publikacji - w omawianej (mniejszej) było zdecydowanie więcej stron (868 w stosunku do 585). Druk nie doczekał się wznowienia.

\subsubsection{Poznań 1820 r.}

Pełny tytuł brzmi: „NOWY PANA NASZEGO JEZUSA CHRYSTUSA TESTAMENT przez X. JAKUBA WUYKA, Societatis Jesu na Polski język przełożony, [...]”.

Analizowane wydanie stanowi przykład bardzo wiernego nawiązania do wydań NTBW z poprzednich wieków (szczególnie do wydania chełmińskiego z 1772 r.). Warto zauważyć (a miało to miejsce jeszcze tylko raz w XIX wieku), że składa ono się z 2 tomów. W pierwszym zawarto Ewangelie, w drugim - pozostałe księgi NT. Nagłówek ma podobną postać jak w omawianych wyżej wydaniach rosyjskich, natomiast w stopce wskazywano miejsca paralelne. Tekst został ułożony w jednej kolumnie, a każdy rozdział rozpoczyna się inicjałem, 
brak natomiast wyróżnionego zapisu nomina sacra. Znaleziono miejsce dla karty z wykazem ewangelii i lekcji, ale już nie dla karty ze spisem treści. Co ciekawe, numer pierwszego rozdziału zapisywano słownie, podczas gdy kolejne numerowano cyframi rzymskimi. Słowo „ewangelia” zapisane zostało według dzisiejszych zasad, podobnie jak imię Jezus. Druk nie ma żadnej oficjalnej aprobaty, jedynie na stronie tytułowej wskazano, że wyszedł „za pozwoleniem zwierzchności" i że jest tłumaczeniem Wujka (ale według wydania z roku 1593/1594, jak wykazuje analiza tekstu). Konwencja strony tytułowej będzie utrzymywana dla kolejnych druków NTBW aż do lat 70. XIX wieku (nie biorąc pod uwagę nieopisanych w tym artykule niektórych wydań NT łączonych ze ST). Druk nie doczekał się wznowienia.

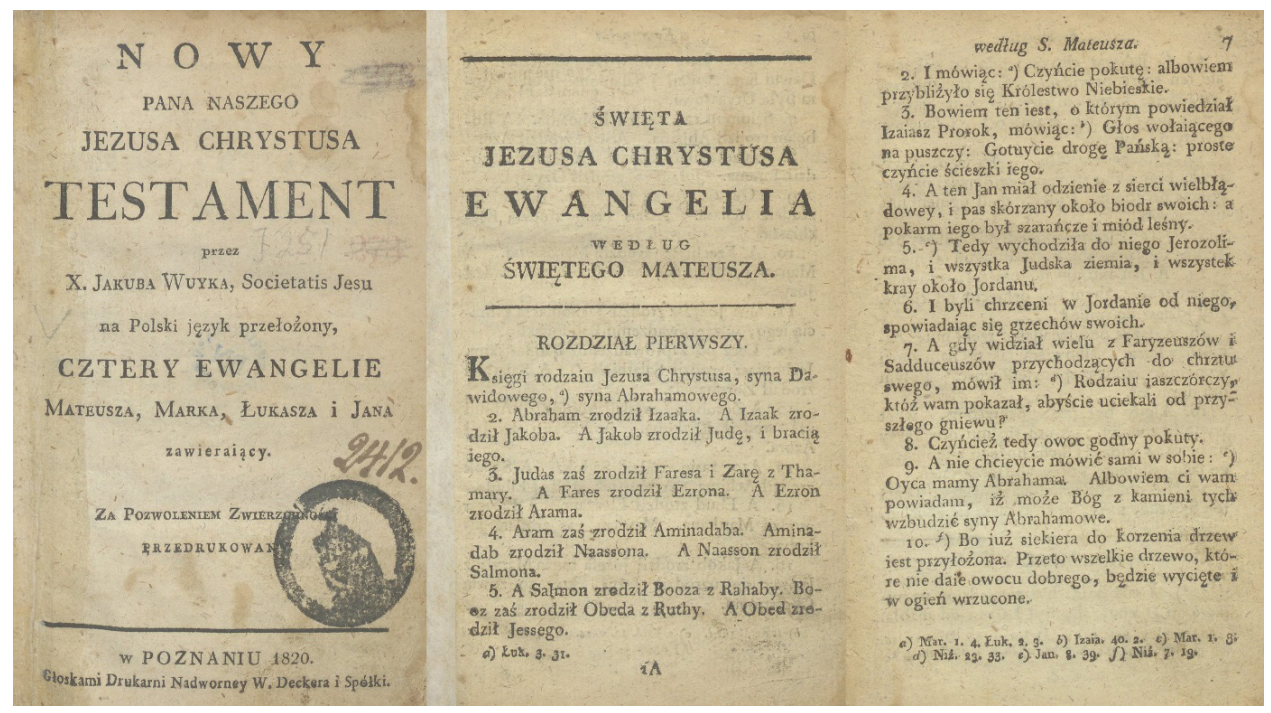

Rys. 15. NTBW, wydanie z roku 1820

Źródło: Biblioteka Narodowa, https://polona.pl [dostęp: 12.06.2021].

W roku 1821 w Moskwie, w drukarni Sieliwanowskiego, ukazał się NT liczony jako trzecia edycja w Rosji. W identycznej formie (choć z podmienioną stroną tytułową) został dołączony do całościowego wydania Biblii z roku 1822. W związku z powyższym został omówiony we wcześniejszym artykule autora.

\subsubsection{Lipsk $1830 \mathrm{r}$.}

Pełny tytuł brzmi: „NOWY PANA NASZEGO JEZUSA CHRYSTUSA TESTAMENT PRZEZ X. JAKUBA WUYKA, SOCIETATIS JESU NA POLSKI JĘZYK PRZEŁOŻONY."

Opisywany model różni się od poprzedniego dwukolumnowym układem, jednotomowym wydaniem oraz brakiem konkordancji. W rzeczywistości obydwa wydania mają dużo cech wspólnych: wariant tłumaczenia (według tekstu Wujka z 1593/1594 r.), układ 
nagłówka, sposób oznaczania numerów rozdziałów, inicjały, brak wyróżnienia nomina sacra, a w końcu podobne informacje na stronie tytułowej. Nie zmienia to jednak faktu, że publikacja z drukarni Tauchnitza jest jedną z uboższych, zarówno pod względem składu, jak i aparatu pomagającego analizować tekst (po raz pierwszy w drukach NT poza tekstem głównym dołączono jedynie stronę przedtytułową i tytułową). Ta dość skromna struktura wydania wpłynęła z pewnością na akceptowalną cenę zakupu. Ukazało się aż 14 kolejnych wydań, co stanowi rekord dla samodzielnych publikacji NT w XIX wieku (opartych na BG i BW ${ }^{29}$. Warto dodać, że to właśnie z niektórych wydań lipskich korzystać mieli Adam Mickiewicz i Juliusz Słowacki ${ }^{30}$.

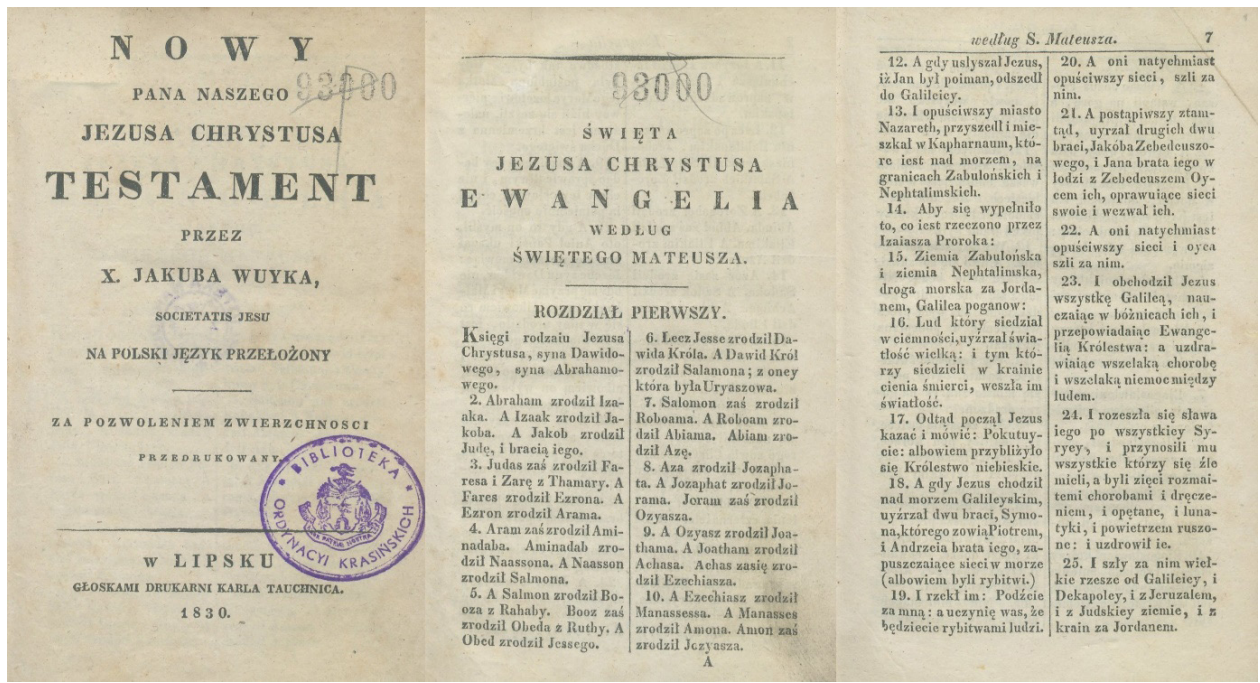

Rys. 16. NTBW, wydanie z roku 1830

Źródło: Biblioteka Narodowa, https://polona.pl [dostęp: 12.06.2021].

W roku 1838 w Lipsku, w drukarni Baumgaertnera, ukazał się NT, który został połączony z wydawanym osobno ST z 1839 r., tworząc całościowe wydanie Biblii. Wydanie

29 Liczba podawanych tu wydań nie jest jednak w pełni potwierdzona. Ze względu na fakt, że kolejne edycje ukazywały się często rokrocznie, istnieje podejrzenie, że były to jedynie warianty tytułowe (czyli wydanie z roku wcześniejszego sprzedawane z nową karta tytułową). Co więcej, aż pięciu wydań $(1833,1837,1844,1845$, 1848) nie odnaleziono w katalogach bibliotecznych, choć ich istnienie potwierdzać mają źródła (patrz np.: M. Ptaszyk, „Okoliczności wydania Biblii Wujka z 1821 roku”, PaL 87/3 [1996] 133; R. Gustaw, „Polskie przekłady Pisma Świętego”, Podręczna encyklopedia biblijna [red. E. Dąbrowski] [Poznań: Księgarnia św. Wojciecha 1959] II, 313; Smereka, „Zarys bibliograficzny”, 75).

30 O korzystaniu z tego wydania wspomina Mirosław Wróbel („Biblijne inspiracje w twórczości Juliusza Słowackiego", Biblia kodem kulturowym Europy [red. S. Szymik] [ABL 9; Lublin: Wydawnictwo KUL 2013] 137-139). Wpływ thumaczenia Wujka (choć trudno jednoznacznie wskazać tu konkretne wydania) dostrzegany jest w twórczości innych wybitnych polskich pisarzy, np. Cypriana K. Norwida, Stanisława Wyspiańskiego czy Leopolda Staffa (zob. S. Koziara, „Biblia Wujka w języku i kulturze polskiej”, Konspekt 14-15 [2003] 131-133). 
z 1838 r. przeszło znaczącą korektę tekstu w roku 1844 (dołączono komentarze pod tekstem, a także wykorzystano tłumaczenie z roku 1599), a od strony graficznej zostało dodatkowo zmienione w roku 1888 (wydanie poznańskie). Wszystkie 3 wersje (które doczekały się jeszcze swoich reedycji) zostały omówione we wcześniejszym artykule autora.

NT ukazał się także we Lwowie, w drukarni Jabłońskiego, w roku 1839 i był sprzedawany lącznie z wydaniem ST z roku 1840.

\subsubsection{Berlin $1859 \mathrm{r}$.}

Pełny tytuł brzmi: „NOWY PANA NASZEGO JEZUSA CHRYSTUSA TESTAMENT PRZEZ X. JAKUBA WUYKA, SOCIETATIS JESU NA POLSKI JĘZYK PRZEŁOŻONY.".

\begin{tabular}{|c|c|c|c|}
\hline 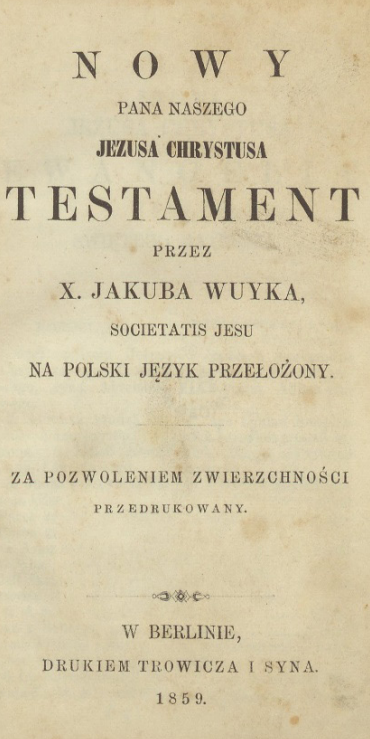 & 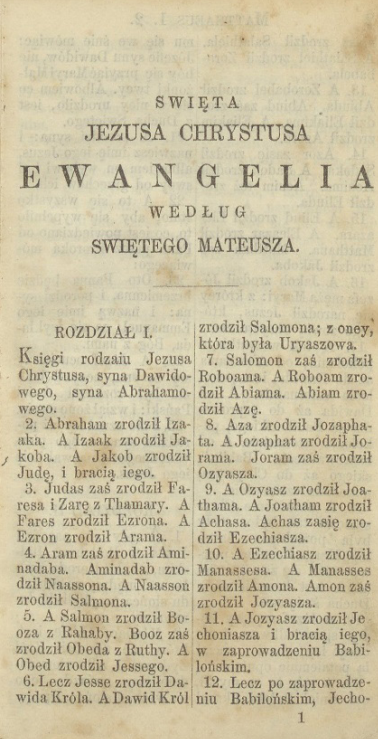 & 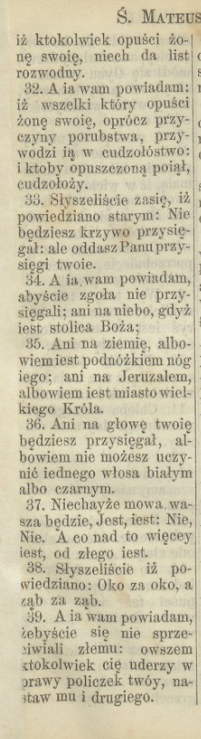 & 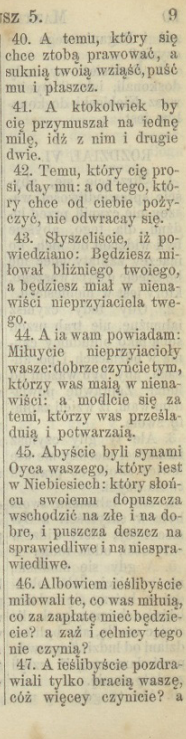 \\
\hline
\end{tabular}

Rys. 17. NTBW, wydanie z roku 1859

Źródło: Biblioteka Narodowa, https://polona.pl [dostęp: 12.06.2021].

Berlińska edycja z 1859 r. zapoczątkowała serię czterech praktycznie bardzo podobnych modeli edytorskich NTBW (sam wzorzec pod względem technicznym jest zresztą zbliżony do wydań berlińskich NTBG). Analizowane wydanie nawiązuje pośrednio także do rozwiązań opisanych w poprzednim punkcie. Wyróżnia je bardziej skomplikowany nagłówek (po raz pierwszy w NTBW w XIX wieku zawarto w nim polski tytuł księgi na stronie recto i łaciński na stronie verso) oraz uproszczony zapis numeracji rozdziałów (za pomocą cyfr rzymskich). Należy przypomnieć, że i w tym wydaniu oparto się na tłumaczeniu Wujka z 1593/1594 r. Edycja nie doczekała się wznowienia dokładnie w takiej samej postaci. 


\subsubsection{Berlin $1862 \mathrm{r}$.}

Pełny tytuł brzmi: „NOWY PANA NASZEGO JEZUSA CHRYSTUSA TESTAMENT PRZEZ X. JAKUBA WUYKA, SOCIETATIS JESU NA POLSKI JEZZYK PRZEEOŻONY.".

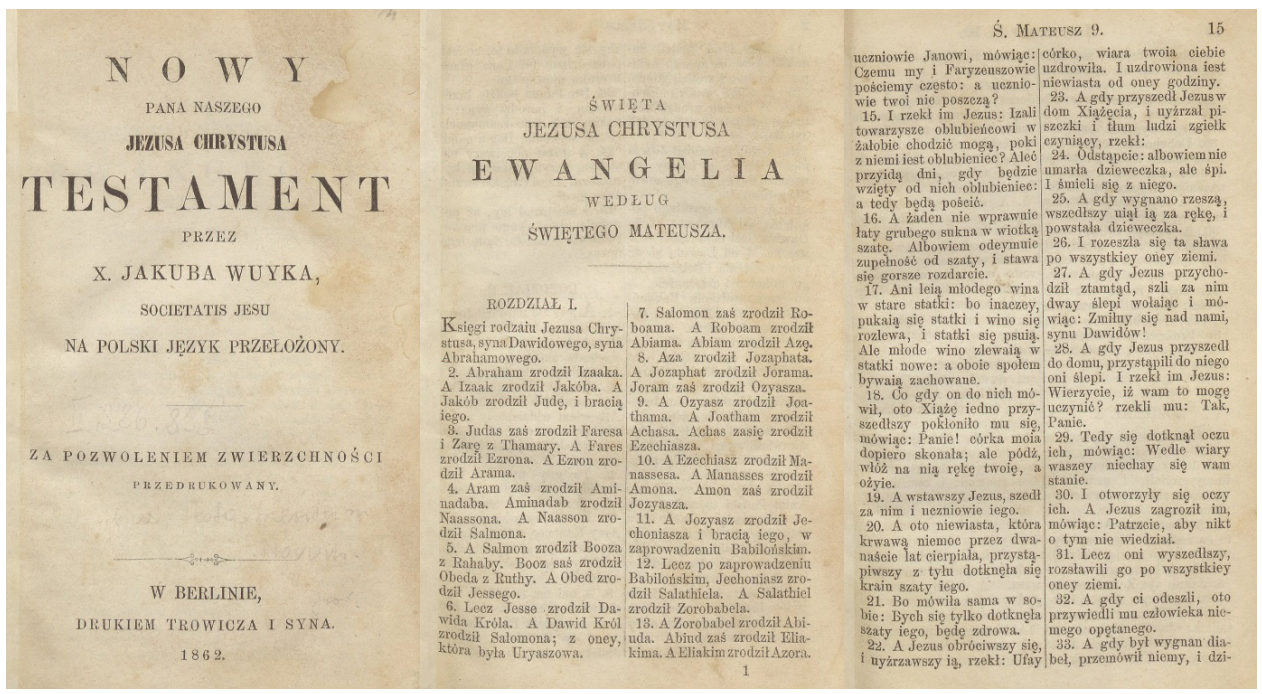

Rys. 18. NTBW, wydanie z roku 1862

Źródło: Biblioteka Narodowa, https://polona.pl [dostęp: 12.06.2021].

Przedstawiany model wydania jest niemal identyczny jak poprzedni. Jest jednak zdecydowanie mniejszy, ale dzięki zastosowaniu innego układu, posiada także mniej stron.

\subsubsection{Berlin $1866 \mathrm{r}$.}

Pełny tytuł brzmi: „NOWY PANA NASZEGO JEZUSA CHRYSTUSA TESTAMENT PRZEZ X. JAKUBA WUYKA, SOCIETATIS JESU NA POLSKI JEZZYK PRZEŁOŻONY.".

W analizowanym wydaniu po raz kolejny mamy do czynienia z modelem powielającym wzór poprzedni. Tym razem różni go głównie inne rozłożenie wyrazów w wierszu i rozmiar książki. Zwraca uwagę forma zapisu imienia Jezus (z wykorzystaniem litery I). Wydanie doczekało się jednego wznowienia. 


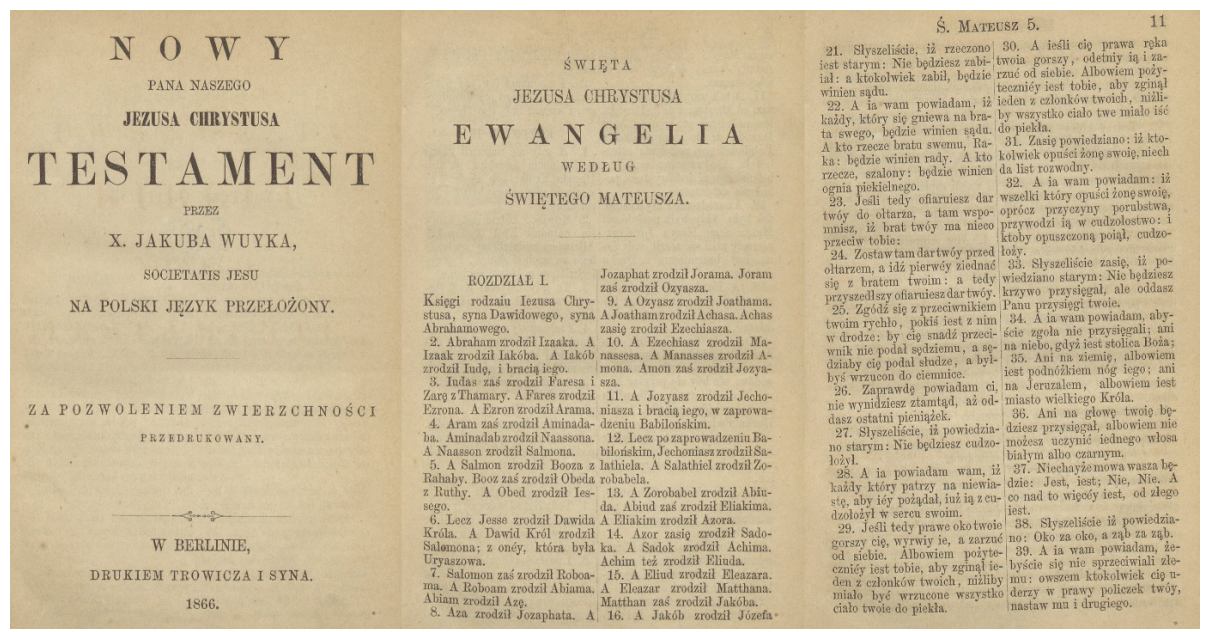

Rys. 19. NTBW, wydanie z roku 1866

Źródło: Biblioteka Narodowa, https://polona.pl [dostęp: 12.06.2021].

\subsubsection{Wiedeń 1866 r.}

Pełny tytuł brzmi: „NOWY PANA NASZEGO JEZUSA CHRYSTUSA TESTAMENT PRZEZ X. JAKÓBA WUYKA, SOCIETATIS JESU NA POLSKI JĘZYK PRZEEOŻONY.”.

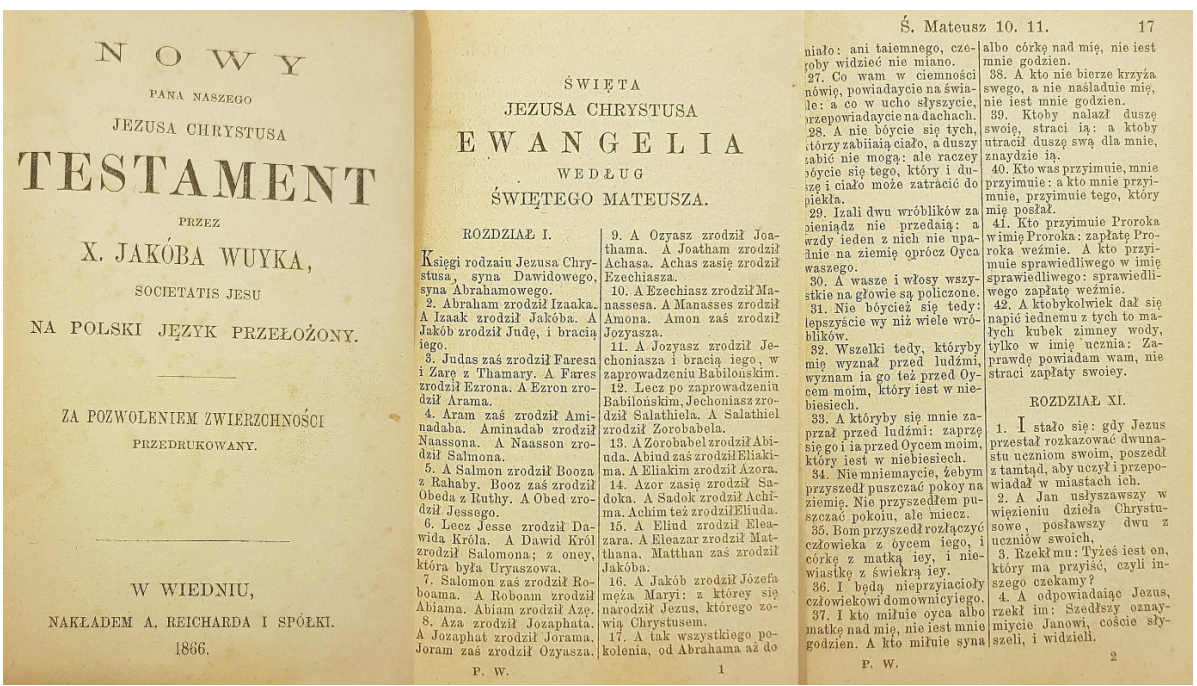

Źródło: Zbiory własne autora.

Rys. 20. NTBW, wydanie z roku 1866

W wydaniu wiedeńskim powtórzono rozwiązania edytorskie zastosowane w poprzedniej edycji. Tym razem wrócono do zapisu imienia Jezus przez J. Wyróżnia je również rozmiar. Wraz z wydaniem NT z roku kolejnego (także wiedeńskim, ale dotyczącym NTBG) 
jest najmniejszym ze wszystkich wydań XIX-wiecznych $(11,5 \times 7 \mathrm{~cm})$. Publikacja nie doczekała się wznowienia.

1.2.9. Wiedeń $1875 \mathrm{r}$.

Pełny tytuł brzmi: „NOWY PANA NASZEGO JEZUSA CHRYSTUSA TESTAMENT PRZEZ X. JAKÓBA WUYKA NA POLSKI JĘZYK PRZEŁOŻONY, Z KILKOMA WEDŁUG GRECKIEGO ORYGINAŁU SPROSTOWANYMI, PONIŻ STRONNICY UMIESZCZONYMI ODMIENNYMI WYRAZAMI.".

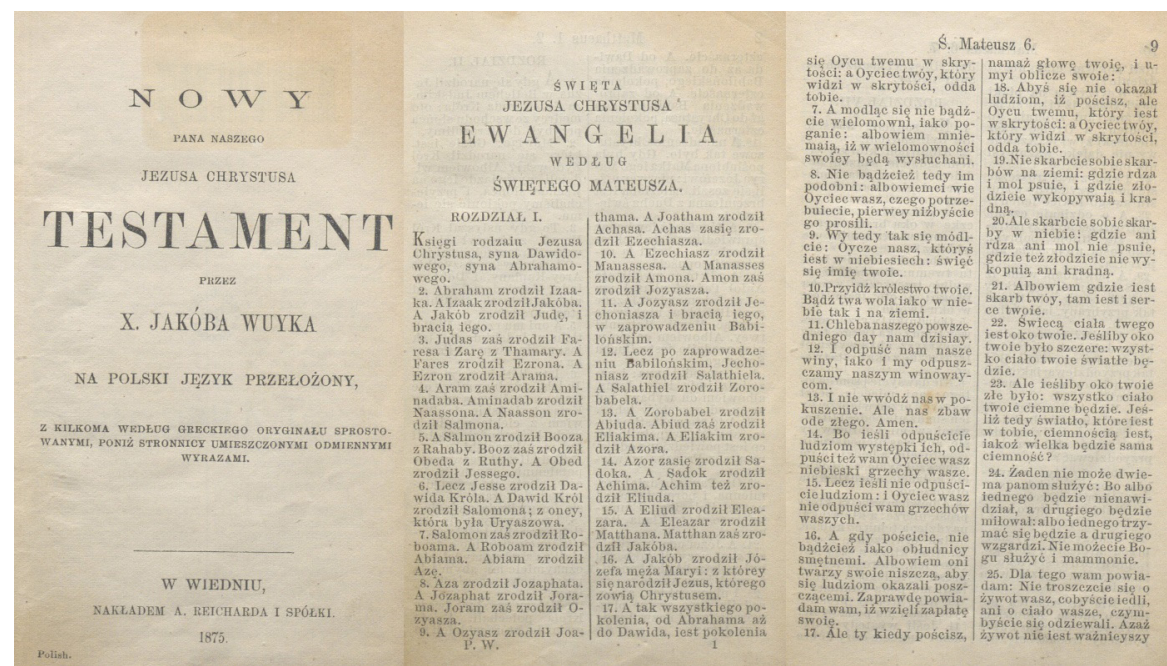

Rys. 21. NTBW, wydanie z roku 1875

Źródło: Biblioteka Narodowa, https://polona.pl [dostęp: 12.06.2021].

Analizowany model, choć nie odbiega znacznie od poprzednich (różni się segmentacją treści w wersach), zasługuje na uwagę. Stanowi pewne rozwiązanie przejściowe. Po raz ostatni wydawca wykorzystał tekst Wujka w thumaczeniu z 1593/1594 r. Na stronie tytułowej pominięto używany od dawna zwrot „za pozwoleniem zwierzchności” i wprowadzono informację o zmianie pewnych słów „według greckiego oryginału”. Zmiany te - jak potwierdza analiza tekstu - nie zostały wprowadzone do tekstu głównego, ale zamieszczone w przypisach. W ten sposób omawiana edycja stanowi pierwszą od wieku XVI zrealizowaną ${ }^{31}$ próbę modyfikacji tłumaczenia Wujka. Należy zauważyć, że jej celem nie było jednak unowocześnienie tekstu, ale zamiar dostosowania tekstu katolickiego do tłumaczeń protestanckich. Druk nie doczekał się wznowienia.

31 Pewne drobne zmiany - jednak tylko w zapisie poszczególnych wyrazów - można było zaobserwować już w wydaniu NTBW z 1647 r. Z kolei w NTBW z 1772 r. odnotowano pierwsze minimalne zmiany w samym tekście. Wynikały one raczej z błędnej korekty aniżeli z intencjonalności wydawcy (zob. H. Duda, „...każda raza Biblia odmieniac" Modernizacja języku przedruków Nowego Testamentu ks. Jakuba Wujka [Lublin: Towarzystwo Naukowe KUL 1998] 98-100, 164-166). 


\subsubsection{Wiedeń $1878 \mathrm{r}$.}

Pełny tytuł brzmi: „NOWY PANA NASZEGO JEZUSA CHRYSTUSA TESTAMENT.Z ŁACIŃSKIEGO NA JĘZYK POLSKI PRZEŁOŻONY PRZEZX. JAKÓBA WUJKA. Dosłowny przedruk z autentycznej edycyi Krakowskiej z r. 1599 potwierdzonej przez Ś. Stolicę Apostolską i J. W. Dunina Arcybiskupa Gnieźnieńskiego i Poznańskiego. Z kilkoma odmiennemi wyrazami sprostowanemi według oryginału greckiego a u dołu stronnicy umieszczonemi.”.

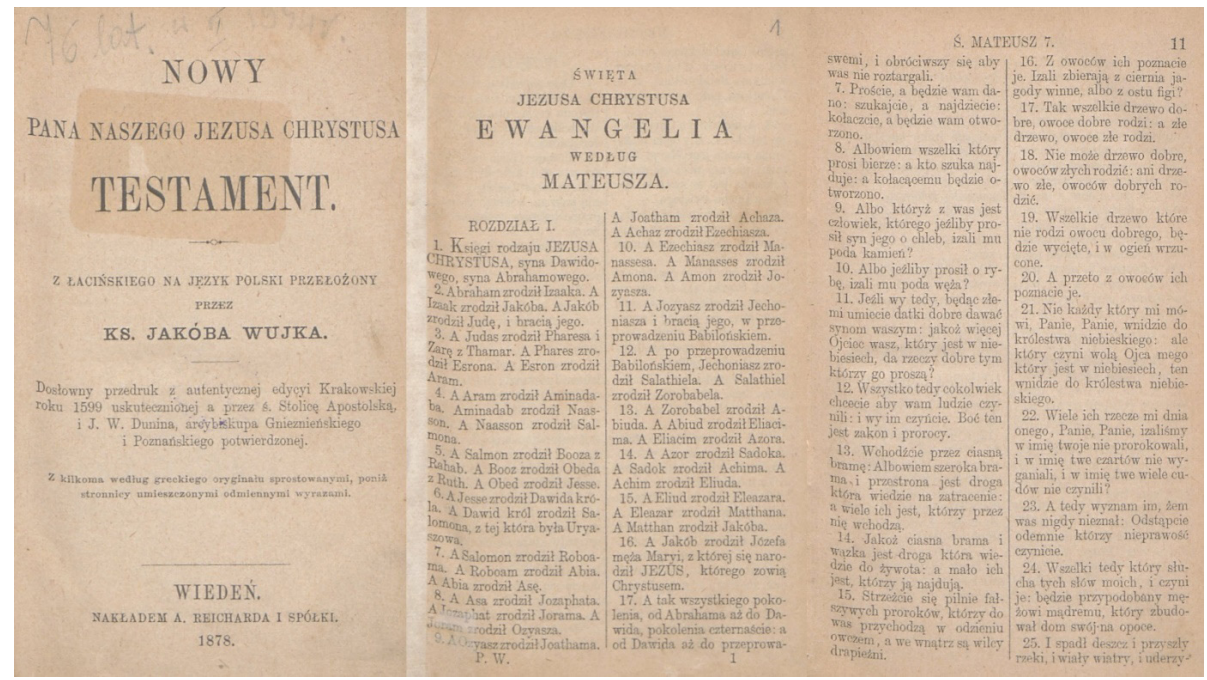

Rys. 22. NTBW, wydanie z roku 1878

Źródło: Biblioteka Narodowa, https://polona.pl [dostęp: 12.06.2021].

Model wiedeński z 1878 r. kontynuuje główne założenia wypracowane w poprzednich edycjach. Widoczne są jednak istotne zmiany. Po raz pierwszy w niemieckich wydaniach NTBW (poza wydaniami Baumagrtnera z Lipska, które, jak wspominano, często tworzyły całość z ST) wykorzystano tłumaczenie Wujka z 1599 r. Strona tytułowa zawiera skróconą aprobatę wydania (sformułowanie, że jest to „dosłowny przedruk z autentycznej edycyi Krakowskiej roku 1599"), mającą zapewne zachęcić katolików do kupna tego właśnie wydania. Zawiera również wzmiankę o odmianie słów „według greckiego oryginału”. Podobnie jak w poprzednim wydaniu, w przypisach umieszczono zmiany dotyczące tłumaczenia poszczególnych wyrazów, wynikające z doktryny protestanckiej. Wrócono do stosowanej niegdyś reguły wyróżniania nomina sacra, a także przywrócono kartę ze spisem treści. Analizowane wydanie doczekało się 3 wznowień. 


\subsubsection{Wiedeń $1892 \mathrm{r}$.}

Pełny tytuł brzmi: „NOWY PANA NASZEGO JEZUSA CHRYSTUSA TESTAMENT.Z ŁACIŃSKIEGO NA JĘZYK POLSKI PRZEŁOŻONY PRZEZ X. JAKÓBA WUJKA. Dosłowny przedruk z autentycznej edycyi Krakowskiej z r. 1599, potwierdzonej przez Ś. Stolicę Apostolską, i J. W. Dunina, Arcybiskupa Gnieźnieńskiego i Poznańskiego. $\mathrm{Z}$ kilkoma odmiennemi wyrazami sprostowanemi według oryginału greckiego a u dołu stronnicy umieszczonemi.".

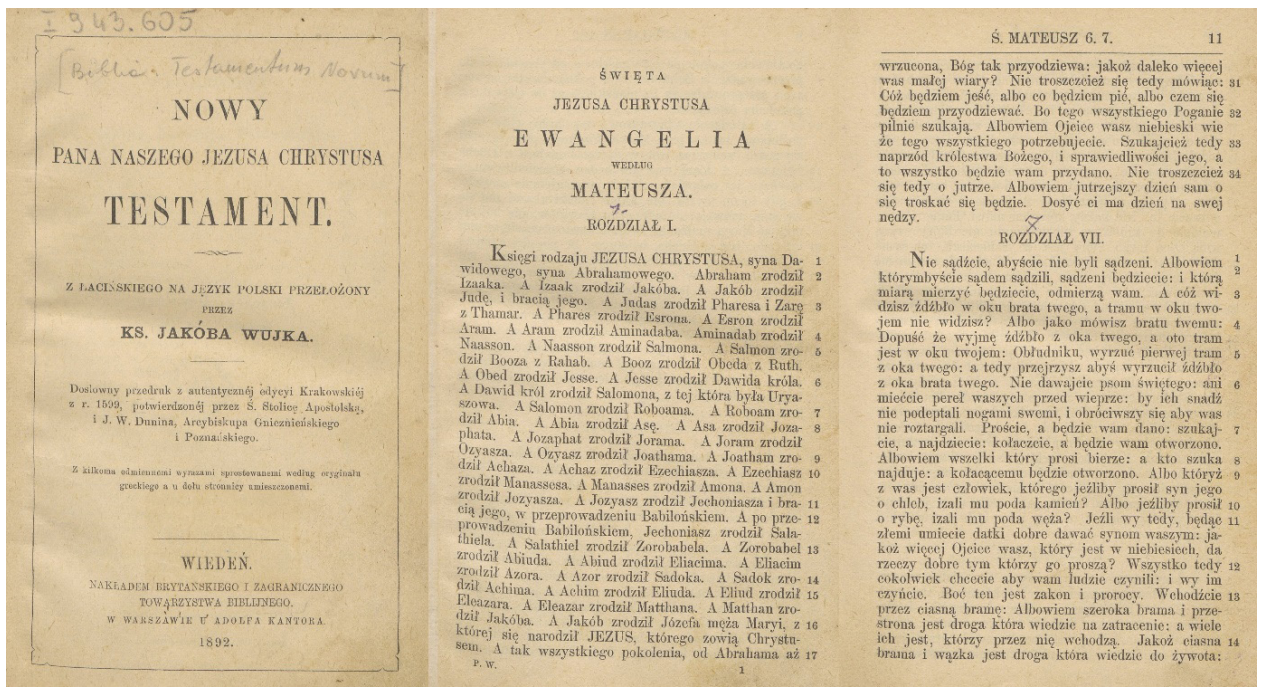

Rys. 23. NTBW, wydanie z roku 1892

Źródło: Biblioteka Narodowa, https://polona.pl [dostęp: 12.06.2021].

Wydanie wiedeńskie z 1892 r. cechuje jedna, ale zasadnicza zmiana w stosunku do modelu omawianego wcześniej, mianowicie układ jednołamowy. Znamienne, że dostępne są egzemplarze o odmiennych stronach tytułowych (z obramowaniem lub bez) i różnych miejscach wydania - w Wiedniu lub Wiedniu - Warszawie ${ }^{32}$. Edycja doczekała się jednego wznowienia.

W roku 1892 w Warszawie, w drukarni Orgelbranda, ukazał się bogato ilustrowany NT, który jednak był tylko wznowieniem części Biblii wydanej w 1889 r.

32 Trudno stwierdzić, czy poprzednie wydania wykazywały podobne różnice. W trakcie analizowania źródeł nie zostały one wychwycone przez autora. 
Pełne tytuły brzmią: „EWANGELIE JEZUSA CHRYSTUSA WEDŁUG ŚW. MATEUSZA - MARKA - ŁUKASZA I JANA” oraz „NOWY TESTAMENT JEZUSA CHRYSTUSA.”

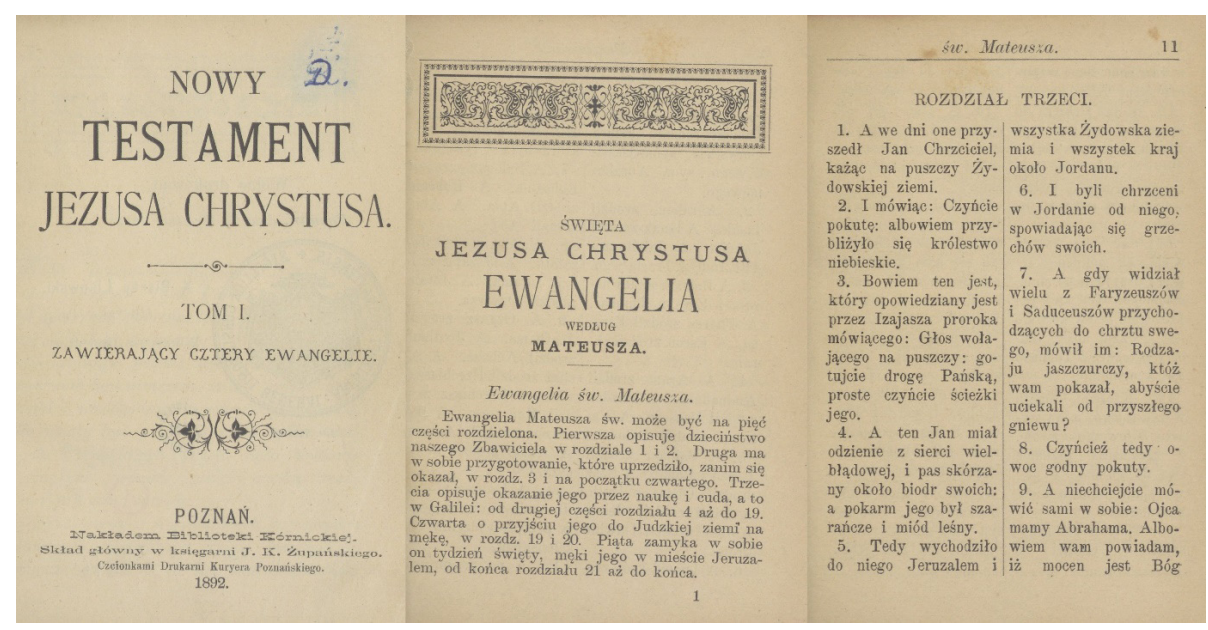

Rys. 24. NTBW, wydanie z lat 1892-1893

Źródło: Biblioteka Narodowa, https://polona.pl [dostęp: 12.06.2021].

Wydanie poznańskie (niekiedy nazywane „kórnickim” z racji publikacji przez Bibliotekę Kórnicką) uzmysławia, jak długo polscy katolicy musieli czekać na poręczne wydanie NT w pełni aprobowane (umieszczono imprimatur) i sygnowane przez władze Kościoła katolickiego (takiej pełnej aprobaty, jak już wspominano, nie miały wydania rosyjskie z początków wieku). Publikacja znacznie różni się od dotychczas omawianych. Co prawda ma ona układ dwukolumnowy (co jest standardem dla tamtych czasów), ale składała się z dwóch tomów (podobnie jak wydanie poznańskie z 1820 r.). W nagłówku znajdujemy dawno niestosowane zestawienie nazwy księgi w języku polskim z numerem strony. Inicjały pojawiają się jedynie na początku księgi. Numery rozdziałów są zapisywane słownie. Użycie leksemu „ewangelia” jest zgodne z dzisiejszymi normami. Na dole strony pojawiają się komentarze będące modyfikacją i skróceniem oryginalnych komentarzy Wujka. Publikacja opatrzona została wstępami - ogólnym do całego wydania oraz poszczególnymi do prawie każdej z ksiąg. Zastosowano w niej elementy graficzne (np. na karcie tytułowej). Na stronie tytułowej brak informacji o wersji tłumaczenia (wątpliwości rozwiewa zarówno imprimatur, jak i lektura wstępu). W publikacji dokonano pewnych modyfikacji związanych z pisownią dawnych form wyrazów występujących w tłumaczeniu Wujka z roku 1599. Wydanie nie było już wznawiane, ale dla formalności należy dodać, że oddzielnie ukazały się zarówno poszczególne Ewangelie, jak i Dzieje Apostolskie (w tych samych latach co cały NT). 


\subsubsection{Lipsk $1896 \mathrm{r}$.}

Pełny tytuł brzmi: „NOWY PANA NASZEGO JEZUSA CHRYSTUSA TESTAMENT.Z ŁACIŃSKIEGO NA JĘZYK POLSKI PRZEŁOŻONY PRZEZ X. JAKÓBA WUJKA. Dosłowny przedruk z autentycznej edycyi Krakowskiej z r. 1599, potwierdzonej przez Ś. Stolicę Apostolską, i J. W. Dunina, Arcybiskupa Gnieźnieńskiego i Poznańskiego. $\mathrm{Z}$ kilkoma odmiennemi wyrazami sprostowanemi według oryginału greckiego a u dołu stronnicy umieszczonemi.".

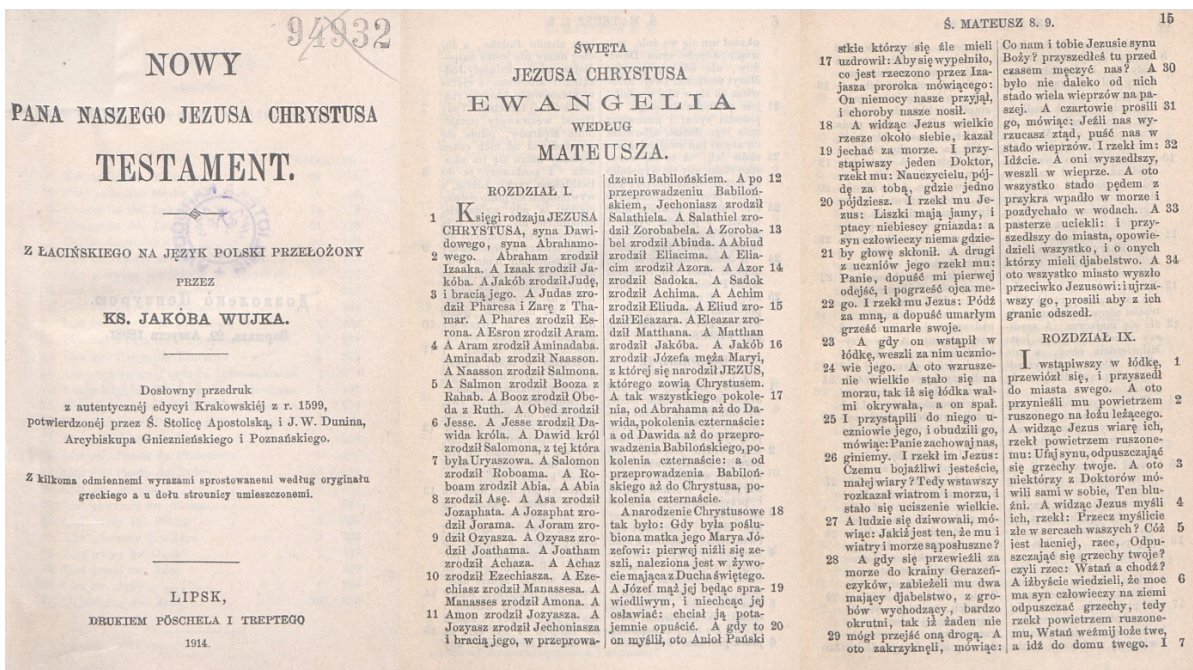

Rys. 25. NTBW, wydanie z roku 1896

Źródło: Zdjęcie wydania z 1914 r. - Biblioteka Narodowa, https://polona.pl [dostęp: 12.06.2021].

Analizowany model stanowi ostatnie z niekatolickich wydań NTBW w XIX wieku. Jest on podobny do poprzednio omawianych wydań niekatolickich (berlińskich i wiedeńskich). Różnicę stanowi rozmieszczenie wierszy na stronie i rezygnacja z łacińskiej nazwy ksiąg w nagłówku. Interesujący jest fakt, że niektóre egzemplarze zawierają swoisty kolorowy frontyspis i mapki. Wydanie doczekało się jeszcze dwóch edycji w XIX wieku (i przynajmniej czterech kolejnych w pierwszej połowie wieku $\mathrm{XX}^{33}$ ). Co więcej - podobnie jak to miało miejsce w przypadku poprzednio opisywanego wydania katolickiego - oddzielnie ukazywały się poszczególne Ewangelie (w roku 1898, ale i niejednokrotnie w XX wieku).

\subsubsection{Warszawa $1900 \mathrm{r}$.}

Pełny tytuł brzmi: „NOWY TESTAMENT JEZUSA CHRYSTUSA. Wydanie zaopatrzone w aprobatę J. E. Księdza Popiela, Arcybiskupa metropolity Warszawskiego.”.

33 Por. Zakonnik, „Biblie w języku polskim”, 488-521. 


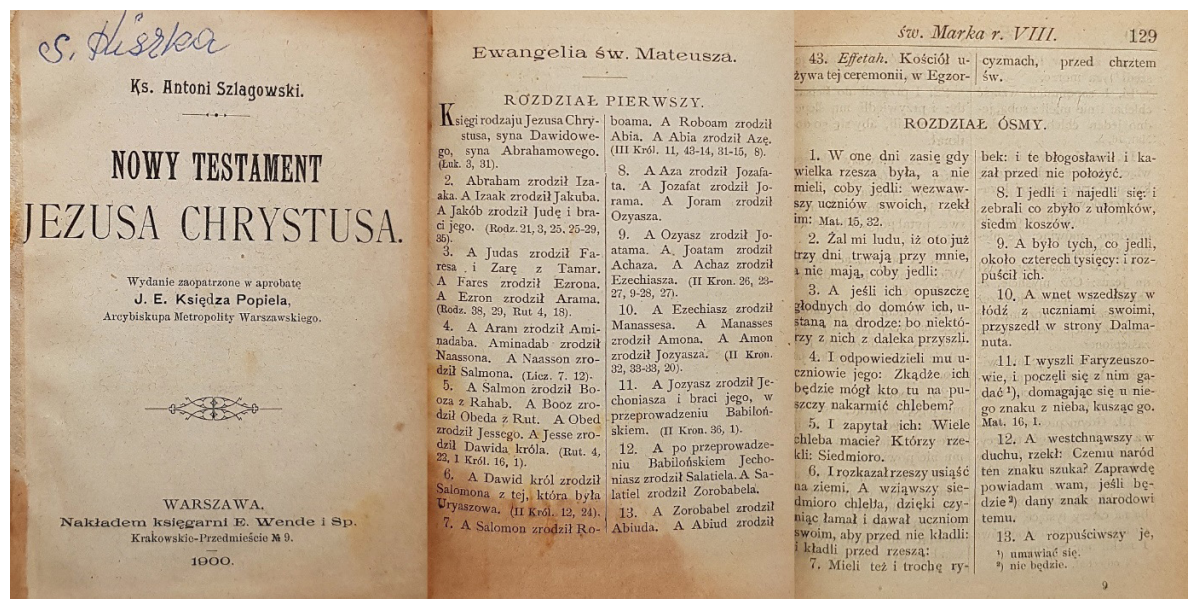

Rys. 26. NTBW, wydanie z roku 1900

Źródło: Zbiory własne autora.

Edycja warszawska z 1900 r. stanowi ważny druk w historii NTBW. Swoim wyglądem przypomina publikację poznańską z lat 1892-1893, ale zawarto w niej elementy dodatkowe. Część z nich dotyczy tekstu głównego (wyróżnienie nomina sacra ${ }^{34}$, umieszczenie konkordancji), pozostałe umieszczono poza nim (karty obejmujące zastosowane skróty, skorowidz, proroctwa, typy biblijne, spis ewangelii i lekcji, mapki i dodatek do map). Brak w nim natomiast sum przed każdą z ksiąg (zamieszczone zostały przed grupami ksiąg), ale - co unikalne - każda księga zaczyna się od nowej strony. Znaczenie omawianego wydania wiąże się też z faktem dokonania pewnych zmian (autorstwa ks. Antoniego Szlagowskiego) w samym tekście, polegających na przeredagowaniu niezrozumiałych archaizmów - zmiany te umieszczano jednak tylko w komentarzach na dole stron. Analizowane wydanie nie mogło się doczekać wznowienia w XIX wieku, niemniej tekst udoskonalany przez ks. Szlagowskiego (choć w innym już modelu edytorskim) ukazał się ponownie trzy razy w wieku XX i stanowił ważne źródło dla polskich katolików aż do modyfikacji tekstu Wujka w 1935 r. (w mniejszym stopniu do ukazania się Biblii Tysiąclecia).

\subsubsection{Wydania niekompletne}

Trzykrotnie w XIX wieku pojawiły się niedokończone edycje NTBW, których redaktorami byli księża katoliccy:

- wydanie drukowane w Krakowie w1872 r. (Drukarnia „Czasu”) ks. Stanisława Stojałowskiego. Ukazał się tylko jeden tomik Nowy Testament x. Jakóba Wujka T.J. z komentarzami btędom wieku odpowiednemi wydatx. St. Stojatowski T, J., Święty Mateusz Tomik 1. Część Isza (stron: XL, 271) ${ }^{35}$. Według niektórych źródeł ${ }^{36}$ miał się ukazać też drugi

34 Tylkow niektórych miejscach (np. Łk, 2,21).

35 Źródło cyfrowe: BibliotekaJagiellońska,https://jbc.bj.uj.edu.pl/dlibra/publication/880859/edition/845908/ content [dostęp: 12.06.2021].

36 Zob. Smereka, „Zarys bibliograficzny”, 81-82. 
tomik (z Ewangelią Marka). Część NT, która została wydrukowana, miała być później $\mathrm{w}$ dużej mierze zniszczona, zapewne z powodu niepełnej zgodności z tłumaczeniem Wujka (ks. Stojałowski miał zmienić pisownię pewnych wyrazów, choć wskazywano także na nieortodoksyjne komentarze) ${ }^{37}$.

- wydanie drukowane w Lublinie w 1890 r. (Drukarnia M. Kossakowskiej) ks. Franciszka Jaczewskiego. Ukazały się Listy Apostolskie i Apokalipsa: PISMO ŚWIĘTE. (NOWY TESTAMENT.) LISTY POWSZECHNE I APOKALIPSA Ś. JANA APOSTOEA. PRZEKEAD KS. JAKÓBA WUJKA T.J. wolnym przektadem, uwagami wstępnymi i przypisami objaśnit Ks. F. Jaczewski Kan. Kat. Lubelskiej. (stron: 109 [s. 1] $)^{38}$. Nie wiadomo, czy plany obejmowały wydanie całości NT.

- wydanie drukowane w Warszawie w 1893 r. (wydawca Leppert \& Comp., Drukarnia „Kupiecka”) ks. Tomasza Kowalewskiego. Ukazały się cztery ewangelie: PISMO ŚWIĘTE. NOWY TESTAMENT PANA NASZEGO JEZUSA CHRYSTUSA. CZĘŚC PIERWSZA. CZTERY EWANGELIE ŚW. Wydanie popularne dla wiernych z tekstem Ks. J. Wujka i komentarzem Ks. Alliolego (stron: 254, IV [s. 2]) $)^{39}$.

\subsubsection{Wydania nieodnalezione}

Na podstawie różnych źródeł można wskazać jeszcze przynajmniej dwa wydania, do których jednak autorowi nie udało się dotrzeć:

- wydanie wydrukowane w Warszawie w 1852 r. (wydane przez Towarzystwo Misjonarzy Angielskich); ma liczyć 506 stron $^{40}$;

- wydanie wydrukowane w Kolonii w $1895 \mathrm{r}^{41}$

\section{Kształt polskich edycji NT w XIX wieku - zestawienie}

Poniżej (tab. 1) zgromadzono najważniejsze informacje o polskich wydaniach NT w XIX wieku. Informacje te są podsumowaniem, ale i uzupełnieniem rozważań zaprezentowanych w poprzednim punkcie pracy.

37 Smereka, „Zarys bibliograficzny”, 81-82.

38 Źródło cyfrowe: Biblioteka Narodowa, https://polona.pl/item/pismo-swiete-nowy-testament-listy-powszechne-i-apokalipsa-s-jana-apostola,MTIwNjUwMzk4/ [dostęp: 12.06.2021].

39 Źródło cyfrowe: Biblioteka Narodowa, https://polona.pl/item/pismo-swiete-nowy-testament-pana-naszego-jezusa-chrystusa-cz-1-cztery-ewangelie-sw,ODk3NDM1MDc [dostęp: 12.06.2021].

40 Wydanie wymieniane przez Barbarę Enholc-Narzyńska („Teksty biblijne”, 146) jako NTBW ze wskazaniem na Estreicher, Bibliografia, 501. Estreicher jednak nie precyzuje, że jest to NTBW. Biorąc pod uwagę fakt, że w 1852 r. ukazało się wydanie NTBG (ten sam wydawca, miejsce i różnica jednej cyfry w zapisie liczby stron) - opisane w 1.1.4 - można przypuszczać, że jest to błąd w identyfikacji tej pozycji.

41 W przypadku tego wydania brak jest jakichkolwiek dodatkowych informacji, wspomina o nim jednak np. Smereka, „Zarys bibliograficzny”, 84 . 
Tab. 1. Polskie wydania NT w XIX wieku - zestawienie modeli edytorskich

\begin{tabular}{|c|c|c|c|c|c|c|c|c|c|c|}
\hline 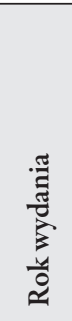 & 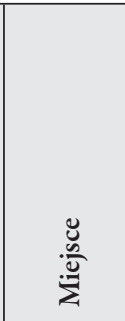 & 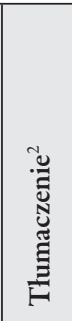 & $\frac{\pi}{5}$ & 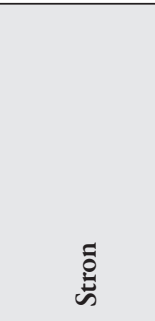 & 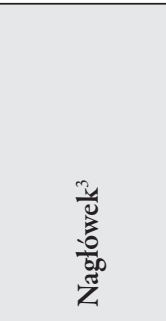 & $\begin{array}{l}\text { चै } \\
\text { के } \\
\text { के }\end{array}$ & 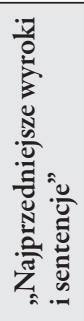 & 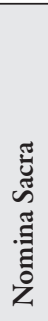 & 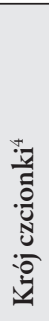 & 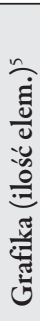 \\
\hline \multicolumn{11}{|c|}{ Wydania NTBG } \\
\hline 1828 & Berlin & GK & Trowicz i Syn & {$[s .4] 606$} & $\mathrm{P}, \mathrm{R}, \mathrm{S}, \mathrm{L}$ & $\mathrm{K}, \mathrm{A}$ & $\mathrm{T}$ & $\mathrm{T}$ & G & $\mathrm{N}$ \\
\hline 1832 & Lipsk & GK & Tauchnitz & [s. 4] 546 & $\mathrm{P}, \mathrm{R}, \mathrm{S}, \mathrm{L}$ & A & $\mathrm{N}$ & $\mathrm{T}$ & G & $\mathrm{N}$ \\
\hline 1834 & Warszawa & G & Gałęzowski & [s. 6] 377 & $\mathrm{PR}, \mathrm{EV}, \mathrm{R}, \mathrm{S}, \mathrm{L}$ & A & $\mathrm{N}$ & $\mathrm{T}$ & $\mathrm{Z}$ & $\mathrm{N}$ \\
\hline 1852 & Warszawa & GK & $\begin{array}{l}\text { Towarzystwo } \\
\text { Misjonarzy } \\
\text { Angielskich }\end{array}$ & [s. 4] 596 & $\mathrm{P}, \mathrm{S}, \mathrm{L}$ & A & $\mathrm{N}$ & $\mathrm{N}$ & $\mathrm{Z}$ & $\mathrm{N}$ \\
\hline 1853 & Londyn & GK & Rypiński i sp. & $\begin{array}{l}{[s .2]} \\
\text { XXX, } 779\end{array}$ & $\mathrm{P}, \mathrm{R}, \mathrm{S}, \mathrm{L}$ & A & $\mathrm{N}$ & $\mathrm{T}$ & $\mathrm{Z}$ & 1 \\
\hline 1862 & Berlin & GK & Trowicz i Syn & [s. 4] 413 & $\mathrm{PR}, \mathrm{EV}, \mathrm{R}, \mathrm{S}$ & A & $\mathrm{N}$ & $\mathrm{N}$ & G & $\mathrm{N}$ \\
\hline 1866 & Berlin & GK & Trowicz i Syn & [s. 4] 5-416 & $\mathrm{PR}, \mathrm{EV}, \mathrm{R}, \mathrm{S}$ & A & $\mathrm{N}$ & $\mathrm{N}$ & $\mathrm{Z}$ & $\mathrm{N}$ \\
\hline 1867 & Wiedeń & GK & Reichard i sp. ${ }^{18}$ & [s. 4] 436 & $\mathrm{PR}, \mathrm{EV}, \mathrm{R}, \mathrm{S}$ & A & $\mathrm{N}$ & $\mathrm{N}$ & $\mathrm{Z}$ & $\mathrm{N}$ \\
\hline 1873 & Berlin & GK & Trowicz i Syn & [s. 4] 421 & $\mathrm{PR}, \mathrm{EV}, \mathrm{R}, \mathrm{S}$ & A & $\mathrm{N}$ & $\mathrm{N}$ & G & $\mathrm{N}$ \\
\hline 1876 & Londyn & GW & $\begin{array}{l}\text { Towarzystwo } \\
\text { Trinitarne } \\
\text { Biblijne }\end{array}$ & [s. ?] 475 & $\mathrm{P}, \mathrm{R}, \mathrm{S}$ & A & $\mathrm{N}$ & $\mathrm{N}$ & $\mathrm{Z}$ & $\mathrm{N}$ \\
\hline 1877 & Wiedeń & GK & Reichard i sp. & $\begin{array}{l}{[s .4] 446} \\
(5-450)\end{array}$ & $\mathrm{PR}, \mathrm{EV}, \mathrm{R}, \mathrm{S}$ & A & $\mathrm{N}$ & $\mathrm{N}$ & Z & $\mathrm{N}$ \\
\hline 1881 & Wiedeń & GW & $\begin{array}{l}\text { Brytańskie } \\
\text { i zagraniczne TB }\end{array}$ & [s. 4] 456 & $\mathrm{P}, \mathrm{R}, \mathrm{S}$ & A & $\mathrm{N}$ & $\mathrm{N}$ & $\mathrm{Z}$ & $\mathrm{R}$ \\
\hline 1898 & Berlin & GK & $\begin{array}{l}\text { Brytyjskie } \\
\text { i zagraniczne TB }\end{array}$ & [s. 2] 3-465 & $\mathrm{PR}, \mathrm{EV}, \mathrm{R}, \mathrm{S}$ & A & $\mathrm{T}$ & $\mathrm{N}$ & G & $\mathrm{N}$ \\
\hline
\end{tabular}




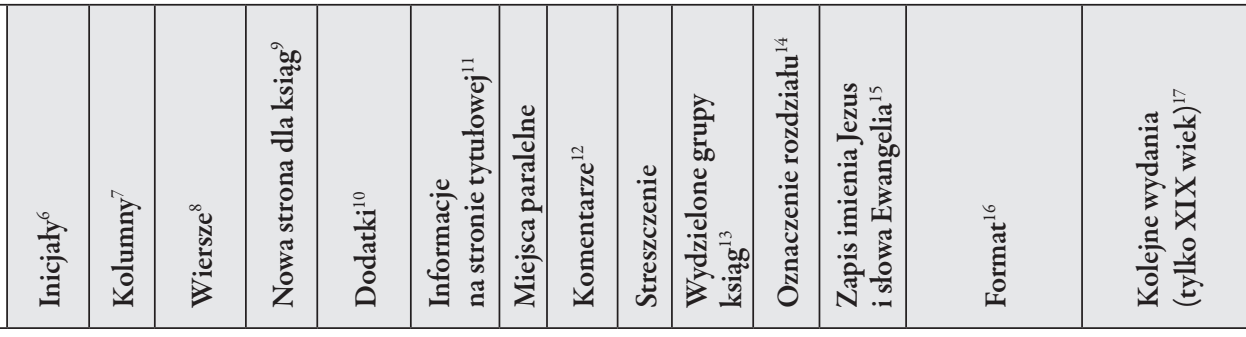

\begin{tabular}{|c|c|c|c|c|c|c|c|c|c|c|c|c|c|}
\hline TR & $2 Z$ & 39 & $\mathrm{~N}$ & E,S & $\mathrm{K}, \mathrm{G}, \mathrm{J}$ & $\mathrm{T}$ & $\mathrm{R}$ & $\mathrm{T}$ & $\mathrm{N}$ & $\mathrm{R}$ & E1,J & $16 \times 11(18)$ & - \\
\hline TR & $2 Z$ & 40 & $\mathrm{~N}$ & $S$ & $\mathrm{~K}, \mathrm{G}, \mathrm{J}$ & $\mathrm{N}$ & $\mathrm{R}$ & $\mathrm{T}$ & $\mathrm{N}$ & $\mathrm{R}$ & E1,J & $15,5 \times 10(18)$ & $\begin{array}{l}\text { L37, L40, } \\
\text { L45, } \\
\text { L50, L57 }\end{array}$ \\
\hline TR & $2 Z$ & $51(52)$ & $\mathrm{N}$ & $S, Y$ & A,G,J & $\mathrm{T}$ & $\mathrm{R}$ & $\mathrm{T}$ & $\mathrm{N}$ & $\mathrm{R}$ & E2,J & $22,5 \times 14(8)$ & - \\
\hline TR & $2 Z$ & $34(35)$ & $\mathrm{N}$ & $S$ & - & $\mathrm{N}$ & $\mathrm{R}$ & $\mathrm{T}$ & $\mathrm{N}$ & $\mathrm{R}$ & E1,J & $16 \times 10(18)$ & - \\
\hline TK & $1 \mathrm{R}$ & $34(35)$ & $\mathrm{N}$ & RS & G & $\mathrm{T}$ & $\mathrm{O} 1, \mathrm{R}$ & $\mathrm{T}$ & $\mathrm{N}$ & $\mathrm{R}$ & E1,J & $16,5 \times 10,5(18)$ & - \\
\hline TRM & $2 Z$ & $39(42)$ & $\mathrm{N}$ & $S$ & $\mathrm{~J}$ & $\mathrm{~N}$ & $\mathrm{R}$ & $\mathrm{T}$ & $\mathrm{N}$ & $\mathrm{R}$ & E1,J & $14 \times 9,5(32)$ & $\begin{array}{l}\text { B64, B66, } \\
\text { B71, B72 }\end{array}$ \\
\hline TRM & $2 Z$ & 42 & $\mathrm{~N}$ & $S$ & $\mathrm{~J}$ & $\mathrm{~N}$ & $\mathrm{R}$ & $\mathrm{N}$ & $\mathrm{N}$ & $\mathrm{R}$ & E1,I & $15 \times 10(18)$ & B67, B72 \\
\hline TR & $2 Z$ & $43(44)$ & TE & $S$ & $\mathrm{~J}$ & $\mathrm{~N}$ & $\mathrm{R}$ & $\mathrm{N}$ & $\mathrm{N}$ & A & E2,I & $11,5 \times 7(48)$ & \\
\hline TR & $2 Z$ & 41 & $\mathrm{~N}$ & $S$ & $\mathrm{~J}$ & $\mathrm{~T}$ & $\mathrm{R}$ & $\mathrm{T}$ & $\mathrm{N}$ & $\mathrm{R}$ & E1,J & $20 \times 13,5(12)$ & \\
\hline TC & $2 Z$ & 42 & $\mathrm{~T}$ ? & $S$ & $\mathrm{~J}$ & $\mathrm{~T}$ & $\mathrm{R}$ & $\mathrm{T}$ & $\mathrm{N}$ & $\mathrm{R}$ & E3,J & $21 x ?(8)$ & \\
\hline TR & $2 Z$ & $39(41)$ & $\mathrm{TE}$ & $S$ & $\mathrm{~J}$ & $\mathrm{~N}$ & $\mathrm{R}$ & $\mathrm{N}$ & $\mathrm{N}$ & $\mathrm{R}$ & E3,J & $12 \times 8(48)$ & $\begin{array}{l}\text { W78, W82, } \\
\text { W83, } \\
\text { WW90, } \\
\text { W95, N96 }\end{array}$ \\
\hline $\mathrm{TC}$ & $2 \mathrm{Z}$ & 39 & $\mathrm{~N}$ & $S$ & $\mathrm{~J}, \mathrm{G}$ & $\mathrm{N}$ & $\mathrm{R}$ & $\mathrm{T}$ & $\mathrm{N}$ & A & E3,J & $20 \times 13,5(12)$ & $\begin{array}{l}\text { WW82, W94, } \\
\text { WW97, W98 }\end{array}$ \\
\hline TK & $2 Z$ & 44 & $\mathrm{~N}$ & $S$ & $\mathrm{~J}$ & $\mathrm{~T}$ & $\mathrm{R}$ & $\mathrm{T}$ & $\mathrm{N}$ & A & E1,J & $20 \times 12,5(16)$ & \\
\hline
\end{tabular}




\begin{tabular}{|c|c|c|c|c|c|c|c|c|c|c|}
\hline 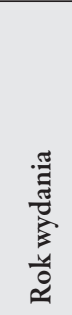 & 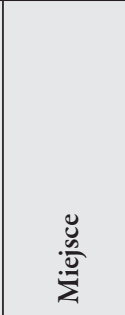 & 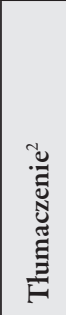 & $\frac{\overparen{D}}{2}$ & ڤే & $\begin{array}{l}\frac{3}{0} \\
\frac{0}{0} \\
\frac{0}{30} \\
\frac{\pi}{z}\end{array}$ & $\frac{\tilde{3}}{\frac{3}{2}}$ & 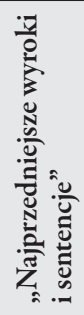 & 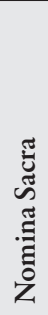 & 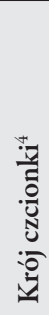 & 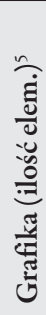 \\
\hline \multicolumn{11}{|c|}{ Wydania NTBW } \\
\hline 1815 & Petersburg & WJ & $\begin{array}{l}\text { Drukarnia } \\
\text { Morska }\end{array}$ & \begin{tabular}{|l}
{$[$ [s. 4] 585} \\
{$[$ s. 3] }
\end{tabular} & $\mathrm{P}, \mathrm{S}, \mathrm{L}$ & A & $\mathrm{N}$ & $\mathrm{T}$ & $\mathrm{Z}$ & $\mathrm{N}$ \\
\hline 1819 & Moskwa & WJ & Semen & \begin{tabular}{|l} 
[s. 4] 868 \\
[s. 2]
\end{tabular} & P,S & A & $\mathrm{N}$ & $\mathrm{T}$ & $\mathrm{Z}$ & $\mathrm{N}$ \\
\hline $1820^{1}$ & Poznań & W & Decker i sp. & $\begin{array}{l}{[\text { s. 4] } 396} \\
\text { [s. 2] } 483 \\
\text { [s. 12] }\end{array}$ & $\mathrm{P}, \mathrm{S}$ & A, E & $\mathrm{N}$ & $\mathrm{N}$ & $\mathrm{Z}$ & $\mathrm{N}$ \\
\hline 1830 & Lipsk & W & Tauchnitz & [s. 4] 586 & P,S,L & A & $\mathrm{N}$ & $\mathrm{N}$ & $\mathrm{Z}$ & $\mathrm{N}$ \\
\hline 1859 & Berlin & W & Trowicz i Syn & [s. 4] 503 & $\mathrm{PR}, € V, \mathrm{R}, \mathrm{S}$ & A & $\mathrm{N}$ & $\mathrm{N}$ & $\mathrm{Z}$ & $\mathrm{N}$ \\
\hline 1862 & Berlin & W & Trowicz i Syn & [s. 4] 448 & $\mathrm{PR}, \mathrm{EV}, \mathrm{R}, \mathrm{S}$ & A & $\mathrm{N}$ & $\mathrm{N}$ & $\mathrm{Z}$ & $\mathrm{N}$ \\
\hline 1866 & Berlin & W & Trowicz i Syn & [s. 2] 422 & $\mathrm{PR}, € \mathrm{~V}, \mathrm{R}, \mathrm{S}$ & A & $\mathrm{N}$ & $\mathrm{N}$ & $\mathrm{Z}$ & $\mathrm{N}$ \\
\hline 1866 & Wiedeń & W & Reichard i sp. & [s. 4] 428 & $P R, E V, R, S$ & A & $\mathrm{N}$ & $\mathrm{N}$ & $\mathrm{Z}$ & $\mathrm{N}$ \\
\hline 1875 & Wiedeń & W & Reichard i sp. & [s. 4] 423 & $\mathrm{PR}, \mathrm{EV}, \mathrm{R}, \mathrm{S}$ & A & $\mathrm{N}$ & $\mathrm{N}$ & $\mathrm{Z}$ & $\mathrm{N}$ \\
\hline 1878 & Wiedeń & WJ & Reichard i sp. & [s. 4] 428 & $\mathrm{PR}, \mathrm{EV}, \mathrm{R}, \mathrm{S}$ & A & $\mathrm{N}$ & $\mathrm{T}$ & $\mathrm{Z}$ & $\mathrm{N}$ \\
\hline 1892 & Wiedeń & WJ & $\begin{array}{l}\text { Brytańskie } \\
\text { i zagraniczne TB }\end{array}$ & [s. 4] 436 & $\mathrm{PR}, \mathrm{EV}, \mathrm{R}, \mathrm{S}, \mathrm{L}$ & A & $\mathrm{N}$ & $\mathrm{T}$ & $\mathrm{Z}$ & $\mathrm{N}$ \\
\hline $\begin{array}{l}1892 \\
-1893^{1}\end{array}$ & Poznań & WK & $\begin{array}{l}\text { Biblioteka } \\
\text { Kórnicka }\end{array}$ & $\begin{array}{l}\text { VII, 509+ } \\
\text { [s. 4] } 619\end{array}$ & $\mathrm{P}, \mathrm{S}, \mathrm{L}$ & A & $\mathrm{N}$ & $\mathrm{N}$ & Z & $P$ \\
\hline 1896 & Lipsk & WJ & Poschel i Trepte & [s. 4] 5-352 & $\mathrm{P}, \mathrm{R}, \mathrm{S}$ & A & $\mathrm{N}$ & $\mathrm{T}$ & Z & $\mathrm{L}$ \\
\hline 1900 & Warszawa & WS & Wende i Sp. & $\begin{array}{l}\text { [s. 2] V, III, } \\
\text { II, 15-874 } \\
\text { [s. 4] }\end{array}$ & $\mathrm{P}, \mathrm{R}, \mathrm{S}, \mathrm{L}$ & A & $\mathrm{N}$ & $\mathrm{T}$ & $\mathrm{Z}$ & W \\
\hline
\end{tabular}




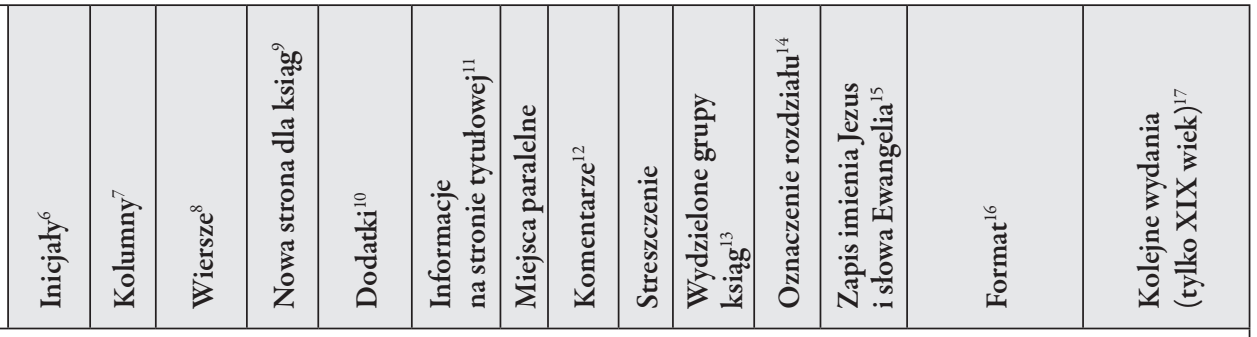

\begin{tabular}{|c|c|c|c|c|c|c|c|c|c|c|c|c|c|}
\hline $\mathrm{N}$ & 1 & 38 & $\mathrm{~N}$ & $\mathrm{~A}, \mathrm{~L}, \mathrm{~S}$ & WW & $\mathrm{N}$ & $\mathrm{G}, \mathrm{R}$ & $\mathrm{T}$ & $\mathrm{N}$ & $\mathrm{R}$ & E4,I & $25 \times 14(8)$ & \\
\hline $\mathrm{N}$ & 1 & 32 & $\mathrm{~N}$ & $\mathrm{~A}, \mathrm{~L}, \mathrm{~S}$ & WW & $\mathrm{N}$ & $\mathrm{G}, \mathrm{R}$ & $\mathrm{T}$ & $\mathrm{N}$ & $\mathrm{R}$ & E4,I & $17,5 \times 10,5(18)$ & \\
\hline TR & 1 & 31 & TE & E,Y & $\mathrm{PZ}, \mathrm{W}$ & $\mathrm{T}$ & $\mathrm{R}$ & $\mathrm{N}$ & $\mathrm{T} 1$ & SR & E2,J & $15,5 \times 9,5(18)$ & \\
\hline TR & $2 Z$ & $35(36)$ & $\mathrm{N}$ & Y & $\mathrm{PZ}, \mathrm{W}$ & $\mathrm{N}$ & $\mathrm{R}$ & $\mathrm{N}$ & $\mathrm{N}$ & SR & E2,J & $15,5 \times 10(18)$ & $\begin{array}{l}\text { L31, L32, } \\
\text { L33?, L36, } \\
\text { L37?, L43, } \\
\text { L44?, } \\
\text { L45?, L47, } \\
\text { L48?, L51, } \\
\text { L54, L56 }\end{array}$ \\
\hline TR & $2 Z$ & 42 & $\mathrm{~N}$ & Y & $\mathrm{PZ}, \mathrm{W}$ & $\mathrm{N}$ & $\mathrm{R}$ & $\mathrm{N}$ & $\mathrm{N}$ & $\mathrm{R}$ & E2,J & $18 \times 10,5(18)$ & \\
\hline TR & $2 Z$ & 42 & $\mathrm{~N}$ & $\mathrm{Y}$ & $\mathrm{PZ}, \mathrm{W}$ & $\mathrm{N}$ & $\mathrm{R}$ & $\mathrm{N}$ & $\mathrm{N}$ & $\mathrm{R}$ & E2,J & $14,5 \times 9,5(32)$ & \\
\hline TR & $2 Z$ & 42 & $\mathrm{~N}$ & - & PZ, W & $\mathrm{N}$ & $\mathrm{R}$ & $\mathrm{N}$ & $\mathrm{N}$ & $\mathrm{R}$ & E2,I & $18 \times 13,5(12)$ & B71 \\
\hline TR & $2 Z$ & 44 & $\mathrm{~N}$ & Y & $\mathrm{PZ}, \mathrm{W}$ & $\mathrm{N}$ & $\mathrm{R}$ & $\mathrm{N}$ & $\mathrm{N}$ & $\mathrm{R}$ & E2,J & $11,5 \times 7,5(48)$ & \\
\hline TR & $2 Z$ & 48 & $\mathrm{~N}$ & Y & SG, W & $\mathrm{N}$ & $\mathrm{O} 1, \mathrm{R}$ & $\mathrm{N}$ & $\mathrm{N}$ & $\mathrm{R}$ & E2,J & $13 \times 8(32)$ & \\
\hline TR & $2 Z$ & 41 & $\mathrm{~N}$ & AS, S & WJ,SG & $\mathrm{N}$ & O1 & $\mathrm{N}$ & $\mathrm{N}$ & $\mathrm{R}$ & E2,J & $12,5 \times 7,5(32)$ & $\begin{array}{l}\text { WW } 83 \text {, } \\
\text { W90, W96 }\end{array}$ \\
\hline TR & 1 & 40 & $\mathrm{~N}$ & AS, S & WJ,SG & $\mathrm{N}$ & O1 & $\mathrm{N}$ & $\mathrm{N}$ & $\mathrm{R}$ & E2,J & $17,5 \times 11(18)$ & W94 \\
\hline TK & $2 Z$ & $26(27)$ & TE & $\begin{array}{l}\mathrm{I}, \mathrm{W} \\
\mathrm{K}, \mathrm{Y}\end{array}$ & - & $\mathrm{N}$ & WJ & $\mathrm{N}$ & $\mathrm{T}$ & $S$ & E2,J & $13 \times 9(32)$ & \\
\hline TR & $2 Z$ & 48 & $\mathrm{~N}$ & AS, S & WJ,SG & $\mathrm{N}$ & O1 & $\mathrm{N}$ & $\mathrm{N}$ & $\mathrm{R}$ & $\mathrm{E} 2, \mathrm{~J}$ & $14,5 \times 8,5(32)$ & L97, L98 \\
\hline TK & $2 \mathrm{Z}$ & 33 & $\mathrm{~N}$ & $\begin{array}{l}\text { W, I, } \\
\text { ZS, } \\
\text { SK, P, } \\
\text { T, DM, } \\
\text { E, AS }\end{array}$ & AP & $\mathrm{T}$ & $\begin{array}{l}\mathrm{W} \\
\mathrm{O} 2\end{array}$ & $\mathrm{~N}$ & $\mathrm{~T}$ & $S$ & E2,J & $12,5 \times 9(32)$ & \\
\hline
\end{tabular}


(1) Wydanie składało się z 2 tomików.

(2) G - tekst BG w wersji z 1632 r., GK - BG w „rewizji królewieckiej”, GW - „rewizja warszawska”, W - tekst BW z wydania 1593/1594 r., WJ - tekst BW z wydania 1599 r., WK - tekst BW z wydania 1599 r. z korektą pisowni (przedmowa Zygmunta Celichowskiego), WS - tekst BW z wydania z 1599 r. z odmianą słów (przedmowa A. Szlagowskiego).

(3) A - sygnatura arkusza, E - miejsca paralelne, K - kustosze, L - oddzielenie linią od tekstu głównego, $\mathrm{E}$ - tytuł księgi po łacinie ( $\mathrm{EV}$ - na stronie verso), $\mathrm{P}$ - tytuł księgi po polsku ( $\mathrm{PR}$ - na stronie recto), $\mathrm{R}$ - numer rozdziału, $S$ - numer strony.

(4) G - czcionka gotycka, Z - antykwa.

(5) L - niektóre wydania mają kolorowy „frontyspis” i mapki, P - 8 finalików, 7 rozet, 2 herby, R - wydania zawierają 2 mapki, W- 4 finaliki, 5 rozet, mapki.

(6) TC - każdy pierwszy wyraz rozdziału pisany wersalikiem z inicjałem, TK - inicjał na początku poszczególnych ksiąg, TR - inicjał na początku każdego rozdziału, TRM - inicjał na początku każdego rozdziału (bardzo mały).

(7) $1 \mathrm{R}-1$ kolumna z ramką, $2 \mathrm{Z}$ - 2 kolumny z linią rozdzielającą.

(8) Wskazywano liczbę wierszy na stronie - w niektórych edycjach ilość wierszy była zmienna (podawano więc liczbę w nawiasie).

(9) TE - tak dla ewangelii.

(10) A - aprobata, AS - aprobata skrócona na stronie tytułowej, DM - dodatek do map, E - wykaz ewangelii i lekcji, I - imprimatur, $\mathrm{K}$ - suma przed każdą księgą, $\mathrm{L}$ - lista omyłek, $\mathrm{P}$ - proroctwa, $\mathrm{R}$ - rozbudowany spis treści, $\mathrm{S}$ - spis treści, SK - skorowidz, T - typy biblijne, W - wstęp, Y - strona przedtytułowa, ZS - zastosowane skróty.

(11) A - BG według wydania amsterdamskiego 1660 r., AP - aprobata abp. Popiela, G - informacja o wydaniu zgodnym z edycją gdańską 1632 r., J - informacja o tłumaczeniu z języka greckiego, K - BG według wydania królewieckiego 1738 r., PZ - druk za „pozwoleniem zwierzchności”, SG - sprostowania tekstu w zgodności z j. greckim, W - tłumaczenie Wujka, WJ - tekst BW z wydania 1599 r., WW - wydanie z Wulgaty w thumaczenie Wujka.

(12) G - część wierszy oznaczono gwiazdką, nie jest znany cel tego zabiegu, O1 - odmiana pewnych słów według „oryginału greckiego”, O2 - odmiana pewnych słów - korekta A. Szlagowskiego, R - część wierszy umieszczono w nawiasach - zapis ten stosowano już zarówno w Biblii Brzeskiej z 1563 r., jak i w NT Wujka z 1593 r. (ale nie w Biblii Wujka z 1599 r.), W - komentarze Wujka wybrane przez A. Szlagowskiego, WJ - zmodyfikowane komentarze Wujka (przez Augustyna Jaskulskiego).

(13) T1 - tomy wydzielają Ewangelie oraz część pozostałą.

(14) A - numer rozdziału zapisany cyframi arabskimi, R - numer rozdziału zapisany liczbami rzymskimi, $S$ - numer rozdziału zapisany słownie, SR - numer pierwszego rozdziału zapisany słownie, kolejne liczbą rzymską.

(15) E1 - ewangielia, E2 - ewangelia, E3 - ewangielija, E4 - ewanielia, I - Iezus, J - Jezus.

(16) Rozmiary niektórych pozycji zostały podane za serwisem polona.pl. W nawiasach podano format drukarski.

(17) Podano inicjał miasta wydania (B - Berlin, L - Lipsk, N - Nowy Jork, W - Wiedeń, WW - Warszawa i Wiedeń) i dwie końcowe cyfry daty.

(18) Druki nakładem Reicherda i sp. ukazywały się w drukarni A. Holzhausena. 
Na schemacie poniżej (rys. 27) przedstawiono zależności edycyjne kolejnych wydań NT w XIX wieku, tworzące swoiste linie modeli edytorskich. Uwzględniono w nim: zastosowany krój czcionki, podobny skład tekstu (np. elementy zawarte w żywej paginie), zakres materiału dodatkowego oraz zawarte narzędzia wspomagające analizę tekstu właściwego (streszczenia, konkordancje itp.). Wydania NT oparte na BG mają belkę z ciemnym kolorem tła, a te oparte na BW - kolor biały. W belkach górnych umieszczono liczbę edycji w ramach poszczególnych gałęzi.

\section{Główne linie modeli edytorskich}

\subsection{Linie edytorskie - wprowadzenie}

$\mathrm{Na}$ prezentowanym schemacie (rys. 27) przedstawiono kilka linii modeli edytorskich dla wydań NT w języku polskim w XIX wieku. Przyjęto podobne założenie jak w artykule nt. całościowych wydań Biblii. Jednak w obecnym opracowaniu autor zdecydował się na bardziej elastyczne podejście i włączenie do poszczególnych linii modeli o podstawowych cechach wspólnych (ogólna koncepcja układu tekstu, rodzaj tłumaczenia, region pochodzenia). Starano się wykazać zarówno związki między konkretnymi modelami, jak i ukazać pewną ewolucję stosowanych rozwiązań. W przypadku gdy poszczególne modele edytorskie były bardzo podobne (wspominano o tym przy okazji ich omawiania w punkcie 1), umieszczano je w jednym elemencie schematu, poprzedzając miejsce ich wydania symbolem kropki.

\subsection{1. „Linia rosyjska NTBW”}

Omawiana linia uwzględnia dwa modele edytorskie, opierające się na tekście Wujka z wydania z 1599 r. (co dla samodzielnych edycji NT jest nowością, gdyż wydania sprzed XIX wieku opierały się na wariancie tłumaczenia z 1593/1594 r.). Wydania mają zamieszczoną aprobatę biskupa oraz wzmiankę o thumaczeniu z Wulgaty (oba elementy zawarte na stronie tytułowej). Układ tekstu jest jednokolumnowy (co jest rzadkością dla samodzielnych edycji NT w XIX wieku). Zastosowano antykwę (co z kolei jest normą dla wydań opartych na tłumaczeniu Wujka). Nagłówek jest uproszczony (zawiera tytuł księgi i numer strony). Wykorzystano numerację rzymską rozdziałów. Występuje słowo „ewanielia” oraz zapis imienia Jezus przez I (całe nomina sacra jest wyróżnione w tekście). Co do zasady brak elementów dodatkowych w tekście głównym (np. komentarzy czy konkordancji), występują jednak streszczenia przed każdym rozdziałem (co jest cechą unikalną dla edycji NT opartych na tłumaczeniu Wujka). Dostępny jest: spis treści, lista omyłek i wspomniana wcześniej aprobata wydania. Zasadniczą różnicą omawianych modeli w linii rosyjskiej jest rozmiar, a co za tym idzie, liczba stron. 
Rys. 27. Linie modeli edytorskich polskich wydań XIX-wiecznych NT

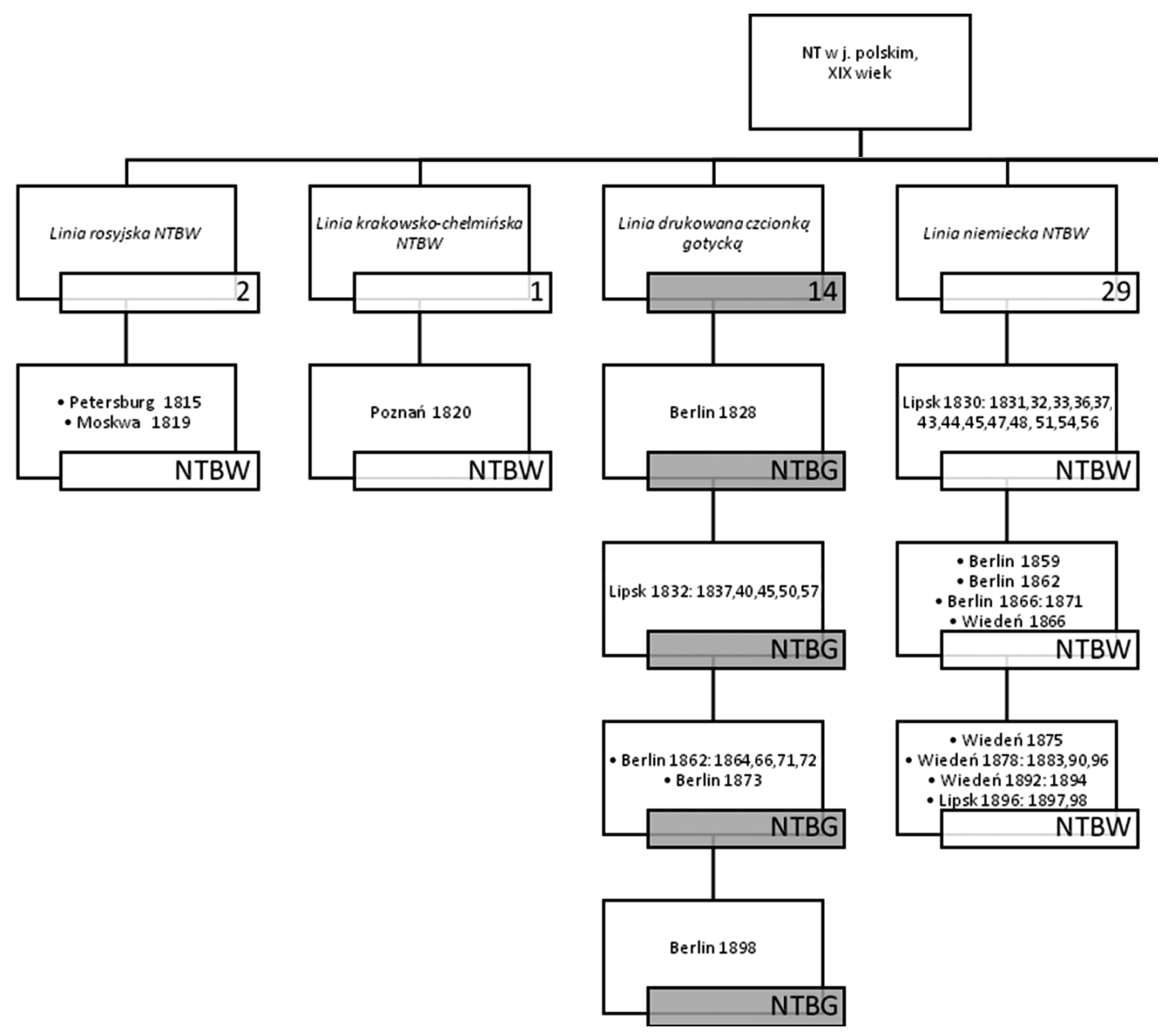




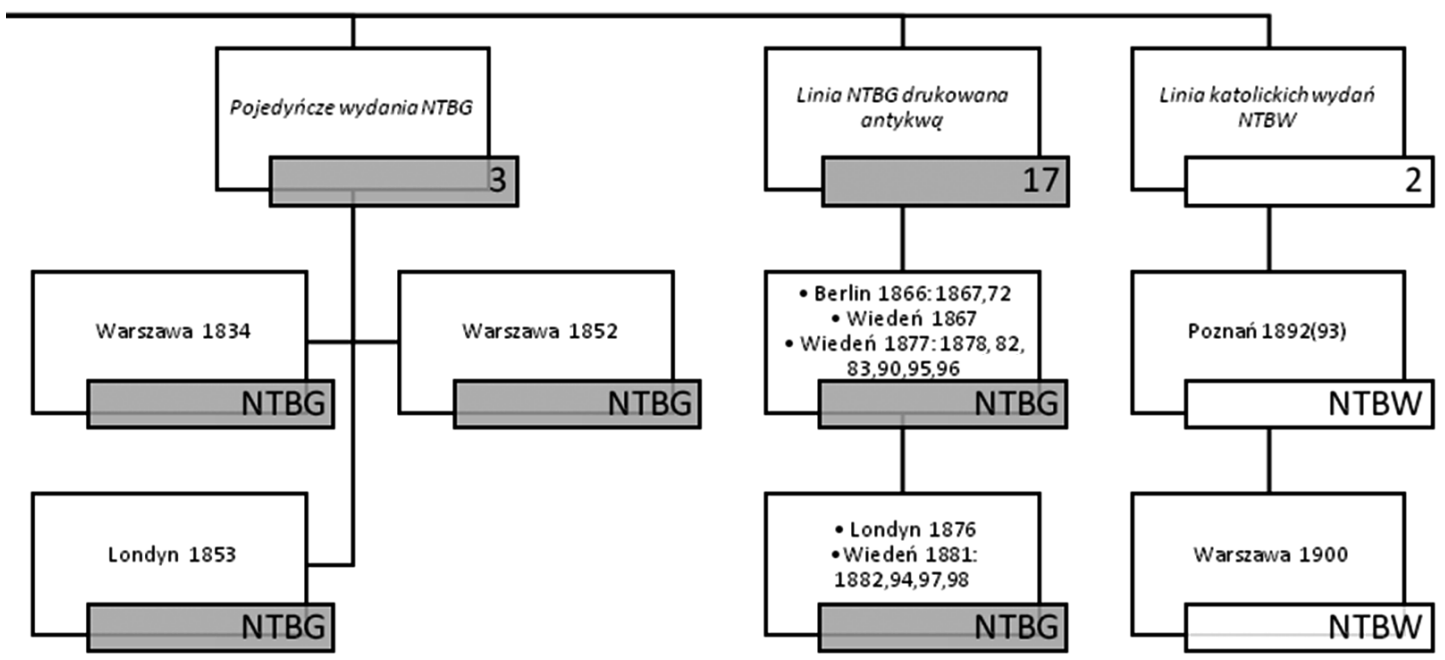




\subsection{2. „Linia krakowsko-chełmińska NTBW”}

Prezentowana linia ma co prawda tylko jednego przedstawiciela w XIX wieku - druk poznański z 1820 r. - ale można zaliczyć do niej również wydanie z Chełmna z 1772 r. Z kolei wydanie z 1772 r. nawiązuje wyraźnie do serii NT wydrukowanych w Krakowie pięciokrotnie $(1594,1605,1617,1621,1647)$. Obydwa druki - poznański i chełmiński - składają się z 2 tomów (Ewangelie i oddzielnie pozostała część NT), a sam układ tekstu jest niemal identyczny. Wydania te opierają się na tłumaczeniu Wujka z roku 1593/1594. Analizowana linia jest pod pewnymi względami zbieżna z poprzednio omawianą. Układ tekstu drukowanego antykwą jest jednokolumnowy (co praktycznie kończy taką formę dla NT w XIX wieku), a sam nagłówek ma równie prosty układ. Zasadniczą różnicą (oczywiście poza samym wariantem tłumaczenia) jest zastosowanie pewnych elementów typograficznych (inicjał rozpoczynający każdy rozdział, słowny zapis numeru pierwszego rozdziału), a także lepszy „aparat naukowy” (występują konkordancje, pewne formy grupowania ksiąg). Warto wspomnieć o użyciu, po raz pierwszy w stosunku do modeli NT w XIX wieku, słowa „ewangelia”. Pozostałe cechy charakteryzujące wydanie poznańskie zostały opisane przy omówieniu tego konkretnego modelu (punkt 1.2.3).

\subsection{3. „Linia drukowana czcionką gotycką”}

W schemacie omawianej linii wyróżniono cztery grupy. Łączy je: zastosowanie czcionki gotyckiej, tłumaczenie oparte na BG w tzw. rewizji królewieckiej, układ dwukolumnowy, zamieszczenie streszczenia przed każdym rozdziałem, inicjał na początku każdego rozdziału (poza ostatnią grupą), brak komentarzy (co jest jednak standardem dla tłumaczeń opartych na BG), konsekwentne stosowanie słowa „ewangielia”, pisanie imienia Jezus przez J oraz rozbudowany nagłówek, w którym umieszczono tytuł księgi, numer strony i rozdziału. Co więcej, rozpoczynając od trzeciej grupy, strony recto i verso zawierają odpowiednio: tytuł księgi po polsku i po łacinie. Poza wspomnianymi podobieństwami w omawianej linii można wskazać pewne różnice w jej poszczególnych grupach. Pierwsza grupa (a właściwie wydanie berlińskie z 1828 r.) posiada zestaw wielu przydatnych dodatków do tekstu. Elementów tych nie mają zazwyczaj kolejne grupy (poza ostatnią). Ciekawie wygląda strona tytułowa, gdzie w przypadku dwóch pierwszych grup widać wyraźne odwołanie do BG jako źródła tłumaczenia, podczas gdy w kolejnych grupach od zasady tej odstąpiono, wspominając jedynie o tłumaczeniu z języka greckiego.

\subsection{4. „Linia niemiecka NTBW”}

Omawiana linia doczekała się największej liczby edycji - aż 29. Proponowana nazwa linii wiąże się z miejscem wydania - na ziemiach niemieckich (wliczając w to wydania wiedeńskie czy wiedeńsko-warszawskie). Tak duża liczba wydań oznacza też większą różnorodność grup modeli edytorskich (w analizowanym przypadku były to 3 grupy). Konkretne modele cechuje dostrzegalne podobieństwo, ale daje się też zauważyć istotne różnice. Większy wpływ miała na nie swoista ewolucja sposobów publikacji NT niż przypadkowość. 
Wszystkie omawiane grupy wykorzystują tłumaczenie Wujka, jednak początkowo publikacje ukazywały się według tłumaczenia z roku 1593/1594, a od roku 1878 zaczęto konsekwentnie stosować tekst z 1599 r. W związku z tym zmieniają się też z czasem informacje zawarte np. na stronie tytułowej. Pierwotnie zamieszczano tam wzmiankę, że wydanie wydrukowano „za pozwoleniem zwierzchności”, aby od wydania z 1878 r. wyraźnie zaznaczać, że są to przedruki z „autentycznej edycyi Krakowskiej roku 1599”. Pomimo tego zapewnienia na stronie tytułowej znajduje się też nota o korekcie pewnych słów „według greckiego oryginału”, co skutkowało pojawianiem się swoistych komentarzy w przypisach. Do roku 1878 widać daleko posunięty minimalizm i brak umieszczania jakiegokolwiek materiału dodatkowego - nawet spisu treści. Wraz z chwilą pojawienia się spisu treści te „protestanckie wydania wujkowe” NT zaczęły także stosować specjalne wyróżnienie formy nomina sacra. Wydania łączył: rozszerzony układ nagłówka (tytuł księgi pisany po polsku na stronie recto, taciński na stronie verso, zamieszczony numer rozdziału oraz strony), druk dwukolumnowy (poza wydaniem wiedeńskim z 1892 r.), rzymska numeracja rozdziałów (dla wydań lipskich Tauchnitza użyto zapisu słownego dla pierwszego rozdziału), antykwa, występowanie małego inicjału na początku każdego rozdziału, stosowanie leksemu „ewangelia” oraz brak konkordancji, komentarzy i streszczeń. Wydania zasadniczo cechował brak grafiki, poza niektórymi egzemplarzami wydania lipskiego Poschela i Treptego.

\subsubsection{Pojedyncze wydania NTBG}

Jak może sugerować sama nazwa, trudno w rozważanym przypadku zakładać w pełni jednolitą linię edytorską. Cechą charakterystyczną uwzględnionych tu wydań jest wykorzystanie tłumaczenia opartego na BG i dość incydentalny charakter wydania (konkretni wydawcy tylko jeden raz zaistnieli jako podmiot publikujący polski NT). Ciekawostką może być też fakt, że każde z wydań wyróżniało się pewnymi osobliwościami tłumaczenia BG. Wydanie z 1834 r. jako jedyne odwoływało się do tłumaczenia BG z wydania amsterdamskiego z 1660 r. (nie uwzględniało więc późniejszej „rewizji królewieckiej”). Wydanie z 1852 r. na stronie tytułowej nie umieściło nawet najmniejszej wzmianki o wariancie tłumaczenia. W końcu wydanie z $1853 \mathrm{r}$. jako jedyne odwoływało się do oryginału thumaczenia BG (przywołany rok 1632, choć sam tekst był po „rewizji królewieckiej”). Konkretne wydania zostały opisane w punktach 1.1.3-1.1.5.

\subsection{6. „Linia NTBG drukowana antykwą”}

Analizowana linia jest podobna do niektórych grup uwzględnionych w linii opartej na czcionce gotyckiej oraz w linii niemieckiej wydań NTBW. Sytuację taką tłumaczy fakt, że każdą z tych trzech linii wydawali w podobnym czasie praktycznie ci sami wydawcy. Jak to zaznaczono w jej nazwie, cechą charakterystyczną jest stosowanie przez wydawców niemieckich antykwy (dzieje się tak dopiero od roku 1866). Linia ta dzieli się na dwie grupy, różniące się pewnymi szczegółami. Pierwszą stanowią wydania NT oparte na „rewizji królewieckiej”. Cechuje ją układ dwukolumnowy (drugą grupę również) oraz stosowanie bardziej rozbudowanego nagłówka z tytułem księgi po polsku na stronie recto i po łacinie na stronie 
verso (dołączono także numer rozdziału i strony). W tekście brak jakichkolwiek elementów dodatkowych (nawet typowego streszczenia przed rozdziałem). Poza tekstem głównym zawarto jedynie spis treści i kartę tytułową, na której znajduje się informacja o tłumaczeniu z języka greckiego. Z elementów urozmaicających skład tekstu można wyróżnić inicjały na początku każdego rozdziału. Co ciekawe, w ramach grupy aż na trzy sposoby zapisywano słowa „ewangelia” - zgodnie z aktualną normą językową, jak i w formach: „ewangielia” oraz "ewangielija”. Brak też konsekwencji w zapisie imienia Jezus (pisanego przez J i przez I). Podobnie niekonsekwentnie postępowano ze sposobem numeracji - używając cyfr arabskich lub rzymskich. W drugiej grupie wykorzystano tłumaczenie związane $\mathrm{z}$ tzw. rewizją warszawską. W tym przypadku w nagłówku nie używano nazwy księgi po łacinie. Nie stosowano również jedynie inicjałów - każdy pierwszy wyraz rozdziału zapisywano wersalikiem (co stanowiło novum dla wydawnictw NT w XIX wieku). Ponadto umieszczono streszczenie ( $w$ wydaniu z $1876 \mathrm{r}$. także konkordancje), a na stronie tytułowej dodano odwołanie do wydania BG z 1632 r. (poza publikacjąz z 1876 r.). Konsekwentnie natomiast stosowano leksem „ewangielija” i zapis imienia Jezus przez J.

\subsection{7. „Linia katolickich wydań NTBW”}

Jak sama nazwa wskazuje, w podpunkcie rozpatrywane są dwa, stosunkowo bliskie modele edytorskie zredagowane w ramach Kościoła katolickiego (jeden dotyczy wydania poznańskiego z lat 1892-1893, drugi - warszawskiego z 1900 r.). Eączy je wiele cech wspólnych: poręczny rozmiar książeczki $(13 \times 9 \mathrm{~cm})$, dwukolumnowy układ tekstu, inicjał w przypadku rozpoczynania każdej księgi, brak streszczeń przed kolejnymi rozdziałami, stosowanie zapisu „ewangelia” i pisownia imienia Jezus przez J. Ponadto wydania posiadają wiele cech niespotykanych w XIX-wiecznych edycjach NT: zapisywanie numeracji wszystkich rozdziałów słownie, zastosowanie stosunkowo bogatego materiału ilustracyjnego, charakterystyczny zestaw elementów dodatkowych (np. rozbudowany wstęp), komentarze wyjaśniające treści NT, w końcu wydzielenie wybranych grup ksiąg i komentarz do nich. W obydwu wydaniach widoczne są również różnice. Publikację warszawską wyróżnia w tekście zapis nomina sacra, wskazanie konkordancji, a w nagłówku numeracja rozdziałów. Dodatkowo obydwa wydania próbują - w odmienny sposób - modyfikować tekst tłumaczenia Wujka z 1599 r. Wydanie poznańskie ogranicza się raczej do korekty pisowni form archaicznych, a w wydaniu warszawskim w komentarzach pojawiają się propozycje użycia innych słów w miejsce przestarzałych.

\subsection{Podsumowanie}

Na podstawie przeprowadzonej analizy linii edytorskich można konstatować, że w omawianym okresie ukształtował się standard wydawniczy, który w pewnej mierze bazował również na rozwiązaniach edytorskich wypracowanych w poprzednich stuleciach. NT generalnie publikowany był w jednym tomie w formacie między $16^{\circ}$ a $32^{\circ}$. Tekst drukowany był 
w układzie dwukolumnowym z linią między kolumnami. Żywa pagina zawierała: tytuł rozdziału (często dwujęzyczny), numer rozdziału oraz numer strony. Do numeracji rozdziału stosowano liczby rzymskie. Nie dołączano żadnych ilustracji, jedynie każdy kolejny rozdział zaczynał się niewielkim inicjałem. W publikacji nie zamieszczano materiału dodatkowego (poza tekstem głównym była dostępna tylko karta tytułowa oraz spis treści). Ograniczono stosowanie wszelkiego rodzaju komentarzy (choć w wydaniach NTBG występują streszczenia przed każdym z rozdziałów). Tekst NTBW zawsze drukowany był antykwą.

\section{Zakończenie}

Podobnie jak miało to miejsce w przypadku całościowych wydań Biblii, również w przypadku edycji NT można wyodrębnić nie tylko określone modele edytorskie, ale i całe linie edytorskie. Zaprezentowanie ich stanowiło zasadniczy cel artykułu. Interesujące wydaje się spojrzenie na aspekt liczbowy, płynący z opracowania. W XIX wieku można zidentyfikować 13 wzorców, na których opierały się wydania NTBG, i 14 wzorców dla wydań NTBW. Zidentyfikowano 4 linie edytorskie NTBW i 3 NTBG. Są to bardzo podobne wartości. Co więcej, po zliczeniu konkretnych edycji okazało się, że w artykule uwzględniono (w ramach analizowanych wzorców) 34 druki NTBG i dokładnie tyle samo druków NTBW. Jest to zdecydowanie inna sytuacja niż w przypadku całościowych wydań Biblii ${ }^{42}$. Wskazane wcześniej dane mogą zaskakiwać, zważywszy na wyraźną przewagę wiernych języka polskiego wyznania katolickiego nad wiernymi różnych odłamów protestanckich. Z drugiej strony, należy pamiętać o minimalnym udziale wydań NT, które zatwierdził Kościół katolicki lub był zaangażowany w druk (w opracowaniu odnotowano tylko dwa takie przypadki). Taki stan rzeczy można spróbować tłumaczyć w różny sposób. Po pierwsze, można uwzględnić aspekt praktyczny - wydawcy, przewidując, że potencjalnych odbiorców NTBW będzie więcej niż NTBG, wybierali ten pierwszy rodzaj tłumaczenia. Po drugie, można założyć, że różne towarzystwa biblijne wydawały NT zgodnie z przyjętą misją ewangelizacyjną, ale kierowaną do różnych odbiorców (unikając w ten sposób oskarżeń o prozelityzm). W końcu można także założyć, że przekład Wujka był na tyle znany, nawet wśród niekatolików, że jego styl w naturalny sposób dominował nad stylem przekładu BG.

$\mathrm{Na}$ zakończenie można postawić pytanie, czy przegląd wydań całościowych Biblii, jak i samego NT, wyczerpuje temat analiz edytorskich związanych z publikacjami tekstów natchnionych w języku polskim w XIX wieku? Czy jako dopełnienie cyklu nie należałoby dokonać jeszcze przeglądu np. edycji psalmów? Analizując materiał publikacyjny związany z tekstem Pisma Świętego w analizowanym okresie, można stwierdzić, że choć

42 W XIX wieku całościowych wydań BG było ponad dwa razy więcej niż wydań BW (zob. Zakonnik, „Modele edytorskie", 369). 
sama identyfikacja wydań psalmów jest interesująca ${ }^{43}$, to jednak czytelnicy, którzy chcieli korzystać z Psałterza do codziennych praktyk religijnych, zostali już w niego zaopatrzeni przy okazji nabywania poręcznych wydań NT (nie wspominając już o całej Biblii). Doszukiwanie się więc pewnych wzorców byłoby tu najczęściej skazane na powielanie wniosków zaprezentowanych w niniejszym i poprzednim opracowaniu. Być może bardziej interesujące byłoby zebranie informacji o osobnych edycjach Ewangelii lub Ewangelii i Dziejów Apostolskich? Wydaje się jednak, że rozkwit tych wydań nastąpił dopiero po XIX wieku ${ }^{44}$. Odrębną kwestią wydaje się natomiast analiza publikowanych w XIX wieku zbiorów kazań czy opowieści biblijnych, zawierających często obszerne perykopy biblijne, a czego przykłady dla wieków poprzednich można odnaleźć w literaturze ${ }^{45}$.

\section{Bibliografia}

Bodrožić, I., „Proces nastanka liturgije časova i kršćansko poimanje vremena u kontekstu benediktinske duhovnosti i pravila", Slovo [Croatia] 71 (2021) 1-25.

Duda, H., „...kazda raza Bibliq odmieniac’" Modernizacja jezyku przedruków Nowego Testamentu ks. Jakuba Wujka (Lublin: Towarzystwo Naukowe KUL 1998).

Enholc-Narzyńska, B., „Teksty biblijne w przekładzie ks. Jana Jakuba Wujka, ich wydania i rozpowszechniane przez Towarzystwo Biblijne w Polsce w XIX i XX wieku", Jan Jakub Wujek ttumacz Biblii na jezyk polski (red. M. Kamińska) (Łódź: Archidiecezjalne Wydawnictw Łódzkie 1994) 136-151.

Estreicher, K., Bibliografia polska XIX. stulecia (Kraków: Uniwersytet Jagielloński 1870) IV.

Gustaw, R., „Polskie przekłady Pisma Świętego”, Podręczna encyklopedia biblijna (red. E. Dąbrowski) (Poznań: Księgarnia św. Wojciecha 1959) II, 299-330.

Komorowska, M., „Kształt edytorski postylli polskich XVI i XVII wieku - w poszukiwaniu staropolskich konwencji wydawniczych", Terminus 17/3 (2015) 317-367.

Kossowska, M., Biblia w jezzku polskim (Poznań: Księgarnia św. Wojciecha 1969) II.

Koziara, S., „Biblia Wujka w języku i kulturze polskiej”, Konspekt 14-15 (2003) 129-133.

Manitius, G., „Historia rewizji warszawskiej Biblii Gdańskiej [1881] i przekładu NT hr. Węgierskiego [1876]”, BibliePolskie.pl, http://bibliepolskie.pl/zzartykuly.php?art_id=15 [dostęp: 12.06.2021].

Pełczyński, G., „Ewangeliczni chrześcijanie-baptyści w Rosji i Związku Radzieckim”, Sensus Historiae 4/3 (2011) $75-79$.

Pietkiewicz, R., Biblia Polonorum. I. Od początku do 1638 roku. V. Biblia Tysiaclecia (1965-2015) (Poznań: Pallottinum 2016, 2015).

Ptaszyk, M., „Okoliczności wydania Biblii Wujka z 1821 roku”, Pamiętnik Literacki 87/3 (1996) 133-154.

Smereka, W, „Zarys bibliograficzny ważniejszych wydań Biblii ks. Jakuba Wujka (1593-1950)”, Ruch Biblijny i Liturgiczny 3 (1950) 64-91.

Sznajderski, T., „Reformacja i polskie przekłady Biblii”, Zagadnienia Rodzajów Literackich 60/4 (2017) 69-83.

43 W XIX wieku ukazało się kilka nowych prób tłumaczeń Psałterza, np. prace: Franciszka Karpińskiego (jeszcze z XVIII wieku, ale licznie wznawiane właśnie w XIX wieku), Bazylego Popiela, Pawła Byczewskiego, Franciszka Pawłowskiego, Kazimierza Buczkowskiego, Kazimierza Bujnickiego czy Izaaka Cylkowa.

44 W katalogu Biblioteki Narodowej trudno się doszukać takich wydań dla XIX wieku.

45 Por. M. Komorowska, „Kształt edytorski postylli polskich XVI i XVII wieku - w poszukiwaniu staropolskich konwencji wydawniczych", Terminus 17/3 (2015) 317-367. 
Wróbel, M., „Biblijne inspiracje w twórczości Juliusza Słowackiego”, Biblia kodem kulturowym Europy (red. S. Szymik) (Analecta Biblica Lublinensia 9; Lublin: Wydawnictwo KUL 2013) 137-146.

Zakonnik, Ł., „Biblie w języku polskim wydane w latach 1801-1945”, Archiwa, Biblioteki i Muzea Kościelne 116 (2021) 483-532.

Zakonnik, Ł., „Modele edytorskie XIX-wiecznych polskich Biblii - próba identyfikacji”, The Biblical Annals $11 / 2(2021) 327-374$.

\section{Załącznik}

W załączniku wskazano cyfrowe źródła skanów NT, z których korzystał autor podczas pisania artykułu. Pierwsze z hiperłącz w przypadku każdej edycji odnalezionej w Bibliotece Narodowej stanowi źródło ilustracji prezentowanej w tekście (licencja - domena publiczna).

\section{Wykorzystane egzemplarze cyfrowe NTBG:}

1828 r., Berlin:

- https://polona.pl/item/nowy-testament-pana-naszego-jezusa-chrystusa-z-grec-jezyka-na-polski-a-teraz,ODcyNTg2MTM/ [dostęp: 12.06.2021].

1832 r., Lipsk:

- https://polona.pl/item/nowy-testament-pana-naszego-jezusa-chrystusa-z-greckiego-jezyka-na-polski-pilnie-i,NjU1ODQ3NjI/ [dostęp: 12.06.2021].

- wydanie z 1845 r., https://polona.pl/item/nowy-testament-pana-naszego-jezusa-chrystusa-z-grec-jezyka-na-pol-pilnie-i-wiernie,ODcyNTg1OTA/ [dostęp: 12.06.2021].

1834 r., Warszawa:

- https://polona.pl/item/nowy-testament-pana-naszego-jezusa-chrystusa-z-grec-jezyka-na-pol-pilnie-i-wiernie,ODcyNTg1OTM/ [dostęp: 12.06.2021].

1852 r., Warszawa:

- https://polona.pl/item/nowy-testament-pana-naszego-jezusa-chrystusa,NjU5OTUxNTU/ [dostęp: 12.06.2021].

1853 r., Londyn:

- https://polona.pl/item/nowy-testament-pana-naszego-jezusa-chrystusa-podlug-edycyi-gdanskiej-przejrzany-i,ODcyNTg1ODk/ [dostęp: 12.06.2021].

1855 r., Wroclaw (wydanie nieodnalezione - informacja za Estreicherem):

- https://www.estreicher.uj.edu.pl/_skany/Bibliografia_XIX_wieku/01_I_Wydanie/04_Tom_ IV/0507_0501.jpg [dostęp: 12.06.2021].

1858 r., Berlin (wydanie nieodnalezione - informacja za Estreicherem):

- https://www.estreicher.uj.edu.pl/_skany/Bibliografia_XIX_wieku/01_I_Wydanie/04_Tom_ IV/0508_0502.jpg [dostęp: 12.06.2021].

1862 r., Berlin:

- wydanie z 1872 r.: https://polona.pl/item/nowy-testament-pana-naszego-jezusa-chrystusa-z-grec-iezyka-na-pol-pilnie-i-wiernie,ODcyNTg2NTQ [dostęp: 12.06.2021].

1866 r., Berlin:

- wydanie z 1867 r.: https://polona.pl/item/nowy-testament-pana-naszego-jezusa-chrystusa-z-grec-jezyka-na-pol-pilnie-i-wiernie,ODcyNTg1OTI [dostęp: 12.06.2021].

1867 r., Wiedeń:

- https://books.google.pl/books?id=WFGJ6Cj119gC\&pg=PP1\&dq=Nowy+Testament+Pana+naszego+Jezusa\&hl=pl\&sa $=X \& v e d=0$ ahUKEwjskuyoq6nlAhWrlYsKHaH0A4k4ChDoAQhJMAY\# $\#_{v}=$ onepage\&q=Nowy\%20Testament\%20Pana\%20naszego\%20Jezusa\&f=false [dostęp: 12.06.2021]. 
1873 r., Berlin:

- https://polona.pl/item/nowy-testament-pana-naszego-jezusa-chrystusa,NjY2NDYyMTM/ [dostęp: 12.06.2021].

1876 r., Londyn (tylko wybrane skany):

- http://bibliepolskie.pl/przeklady.php?tid=101 [dostęp: 12.06.2021].

1877 r., Wiedeń:

- https://polona.pl/item/nowy-testament-pana-naszego-jezusa-chrystusa-z-grec-jezyka-na-pol-pilnie-i-wiernie,ODcyNTg2MTQ/ [dostęp: 12.06.2021].

- wydanie z 1882 r., Warszawa-Wiedeń: https://polona.pl/item/nowy-testament-pana-naszego-jezusa-chrystusa-z-greckiego-jezyka-na-polski-pilnie-i,ODk3NTA1MDA/ [dostęp: 12.06.2021].

1881 r., Wiedeń:

- wydanie z 1894 r.: https://polona.pl/item/nowy-testament-pana-naszego-jezusa-chrystusa,ODk3NTA1MDc [dostęp: 12.06.2021].

1898 r., Berlin:

- https://polona.pl/item/nowy-testament-pana-naszego-jezusa-chrystusa-z-grec-jezyka-na-pol-pilnie-i-wiernie,ODk3NTA1MDE/ [dostęp: 12.06.2021].

\section{Wykorzystane egzemplarze cyfrowe NTBW:}

1815 r., Petersburg:

- https://polona.pl/item/nowy-testament-pana-naszego-iezusa-christusa,ODcyNTg2MTY/ [dostęp: 12.06.2021]. 1819 r., Moskwa:

- https://polona.pl/item/nowy-testament-pana-naszego-iezusa-christusa,ODcyNTg2MjM/ [dostęp: 12.06.2021].

1820 r., Poznań:

- https://polona.pl/item/nowy-pana-naszego-jezusa-chrystusa-testament-cztery-ewangelie-mateusza-marka-lukasza,OTI4ODc3NDI/ oraz https://polona.pl/item/nowy-pana-naszego-jezusa-chrystusa-testament-dzieje-apostolskie-listy-swietych-pawla,OTI4ODc3Mzc/ [dostęp: 12.06.2021].

1830 r., Lipsk:

- https://polona.pl/item/nowy-pana-naszego-jezusa-chrystusa-testament-przez-jakuba-wuyka-na-polski-jezyk,NjU5MjA4OTg/ [dostęp: 12.06.2021].

- wydanie z 1854 r.: https://polona.pl/item/nowy-pana-naszego-jezusa-chrystusa-testament,OTI4ODc3NDM/ [dostęp: 12.06.2021].

1859 r., Berlin:

- https://polona.pl/item/nowy-pana-naszego-jezusa-chrystusa-testament-przez-jakuba-wuyka-na-polski-jezyk,ODcyNTg2MTE [dostęp: 12.06.2021].

1862 r., Berlin:

- https://polona.pl/item/nowy-pana-naszego-jezusa-chrystusa-testament-przez-jakuba-wuyka-na-polski-jezyk,ODcyNTg2MDM/ [dostęp: 12.06.2021].

1866 r., Berlin (brak skanu - egzemplarze odnalezione za WorldCat):

- https://www.worldcat.org/title/nowy-pana-naszego-jezusa-chrystusa-testament/oclc/883535271 [dostęp: 12.06.2021].

1866 r. Wiedeń (brak skanu - egzemplarze odnalezione za WorldCat):

- https://www.worldcat.org/title/nowy-pana-naszego-jezusa-chrystusa-testament-przez-x-jakoba-wuyka-na-polski-jezyk-przeozony/oclc/57012422 [dostęp: 12.06.2021].

1875 r., Wiedeń:

- https://polona.pl/item/nowy-pana-naszego-jezusa-chrystusa-testament,OTI4ODc3NDQ/ [dostęp: 12.06.2021].

1878 r., Wiedeń:

- https://polona.pl/item/nowy-pana-naszego-jezusa-chrystusa-testament,ODcyNTg2NDA/ [dostęp: 12.06.2021]. 
- wydanie z 1896 r., Wiedeń: https://polona.pl/item/nowy-pana-naszego-jezusa-chrystusa-testament,ODk3ODEyNjQ/ [dostęp: 12.06.2021].

\section{2 r., Wiedeń:}

- https://polona.pl/item/nowy-pana-naszego-jezusa-chrystusa-testament,ODk3NjQ1Mzk [dostęp: 12.06.2021]. 1892-1893, Poznań:

- https://polona.pl/item/nowy-testament-jezusa-chrystusa-t-1-zawierajacy-cztery-ewangelie,ODk3NDM$1 \mathrm{MTc} / \mathrm{i}$ https://polona.pl/item/nowy-testament-jezusa-chrystusa-t-2-zawierajacy-dzieje-apostolskie-listy-apostolskie,ODk3NTA1MTU [dostęp: 12.06.2021].

\section{6 r., Lipsk:}

- wydanie z 1914 r.: https://polona.pl/item/nowy-pana-naszego-jezusa-chrystusa-testament,ODk3NjM4NTA/ [dostęp: 12.06.2021].

1900 r., Warszawa (brak skanu - egzemplarze odnalezione za WorldCat):

- https://www.worldcat.org/title/nowy-testament-jezusa-chrystusa/oclc/179738152\&referer=brief_results [dostęp: 12.06.2021]. 
